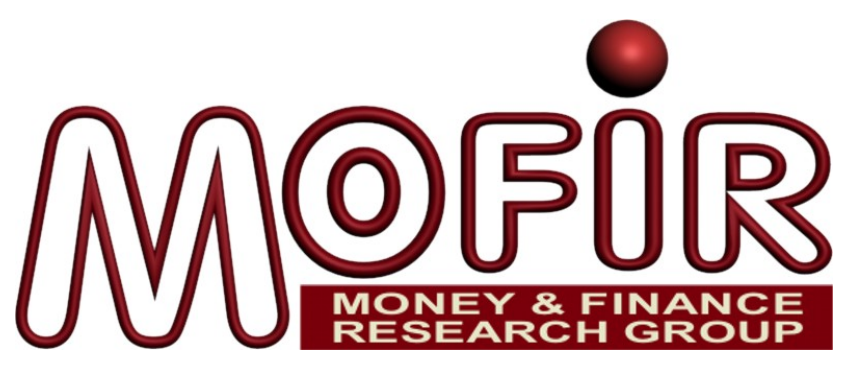

\title{
Multinational Banking in Europe: Financial Stability and Regulatory Implications. Lessons from the Financial Crisis
}

\author{
Giorgio Barba Navaretti \\ University of Milan \\ Centro Studi Luca d'Agliano \\ Giacomo Calzolari \\ University of Bologna \\ CEPR \\ Centro Studi Luca d'Agliano \\ Alberto Franco Pozzolo \\ Università degli Studi del Molise \\ $M o F_{I} R$ \\ Centro Studi Luca d'Agliano \\ Micol Levi \\ Centro Studi Luca d'Agliano
}

MoFiR working paper $n^{\circ} 40$

April 2010 


\title{
Multinational Banking in Europe: Financial Stability and Regulatory Implications Lessons from the Financial Crisis*
}

\author{
by \\ Giorgio Barba Navaretti (University of Milan and Centro Studi Luca d'Agliano) \\ Giacomo Calzolari ( University of Bologna, CEPR and Centro Studi Luca d'Agliano) \\ Alberto Franco Pozzolo (University of Molise, Centro Studi Luca d'Agliano and MoFiR) \\ Micol Levi (Centro Studi Luca d'Agliano)
}

Second Draft Prepared for Economic Policy

March 15, 2009

\begin{abstract}
This paper examines whether multinational banks have a stabilising or a destabilising role during times of financial distress. With a focus on Europe, it looks at how these banks' foreign affiliates have been faring during the recent financial crisis. It finds that retail and corporate lending of these foreign affiliates has been stable and even increasing between 2007 and 2009. This pattern is related to the functioning of the internal capital market through which these banks funnel funds across their units. The internal capital market has been an effective tool to support foreign affiliates in distress and to isolate their lending from the local availability of financial resources, notwithstanding the systemic nature of the recent crisis. This effect has been particularly large within the EU integrated financial market and for the EMU countries, thus showing complementarity between economic integration and multinational banks' internal capital markets. In light of these findings, this paper supports the call for an integration of the European supervisory and regulatory framework overseeing multinational banks. The analysis is based on an analytical framework which derives the main conditions under which the internal capital market can perform this support function under idiosyncratic and systemic stresses. The empirical evidence uses both aggregate evidence on foreign claims worldwide, and firm-level evidence on the behaviour of banking groups' affiliates, compared to standing alone national banks.
\end{abstract}

* We would like to thank Giorgio Basevi, Paolo Manasse, the Editor (Philippe Martin) and four anonymous referees for their very helpful comments and suggestions on the first draft of this paper. All remaining errors are of course our own. 


\section{Introduction}

Multinational banks (MNBs) have been growing fast, especially within the EU. The size and the global interconnectedness of their activities have risen serious concerns on their potential systemic effects. They have been considered among the main culprits of the present financial crisis. Many of the financial institutions that had to be bailed out or supported with public funds in 2008 and 2009 in Europe and in the US were MNBs. ${ }^{1}$ Special supervisory mechanisms and prudential requirements for these banks are at the core of most reform proposals of regulation and supervision of financial markets. ${ }^{2}$

However, these concerns often rest on a superficial assessment of the role and the activities of MNBs. The aim of this paper is providing a comprehensive assessment of the behaviour of MNBs in the last decade and during the recent crisis. The analysis will be based on an in-depth theoretical evaluation of the functioning of the internal capital market (ICM henceforth), through which MNBs funnel funds across their global operations, and on macro and firm level evidence. We will addresses the question of whether MNBs have a stabilizing or destabilizing role during times of financial distress. There are several well grounded economic arguments supporting the claim that this type of banks can rather have a stabilising effect on global financial markets and on the economies of the host countries where they operate. Also, the empirical evidence, including for the period of the recent financial crisis, shows that these banks have kept being a substantial and stable source of financial resources for host economies.

The analysis is especially focussed on the operations that MNBs carry out in the host countries, where they have foreign affiliates. Indeed, these banks have increasingly been competing with domestic institutions in activities which are to a large extent non tradable, like retail banking and corporate loans to small businesses, and which imply a high degree of local intermediation of funds through affiliates based in host countries (Mc Cauley, Mc Guire and von Peter 2010). Their role has been growing especially fast within the integrated financial market of the EU and in emerging economies, where domestic institutions are weak. The financial claims towards residents in host countries held by MNBs through their affiliates account today for more than half of the total foreign claims of the banking system worldwide. ${ }^{3}$

This type of banking is of course similar to what domestic institutions do and inherently less volatile and more intertwined to the real economy than wholesale cross border activities. However, it is also quite clear that MNBs have greater ease than domestic banks in channelling funds across their units world-wide, because of their role in the wholesale market and through internal transfers

\footnotetext{
${ }^{1}$ For example the Royal Bank of Scotland, Lloyds, ING, Fortis, Dexia, Merril Lynch, Citigroup and several others.

${ }^{2}$ See for example the proposal for the European Banking Authority by the EU, Turner (2009) and FSA (2009).

${ }^{3}$ Which include the cross-country operations of national, stand alone banks.
} 
of liquidity and assets, indeed the ICM. In this respect, precisely their deep involvement in the retail and corporate market of local economies, associated with a high potential for mobilising activities cross border, has risen concerns that these financial institutions might be a cause of volatility and instability in the countries where they operate. ${ }^{4}$

The availability of a global ICM can indeed affect stability in both directions: MNBs can either support foreign affiliates in distress or, rather, funnel resources away thereby creating potential distress. The theoretical framework we develop here, though, shows that is possible to identify clearly the conditions under which the bright side of ICMs (i.e. their ability to support affiliates in distress and to allocate resources efficiently on the basis of global returns) is more likely to emerge.

Our evidence of the limited volatility of aggregate claims during the financial crisis supports the view that MNBs can enhance financial stability, even in times of systemic financial distress. Also, the empirical analysis we carry out on a large panel of banks in the EU27 countries between 2000 and 2008, provides robust evidence that foreign affiliates of MNBs, compared to standalone domestic banks and domestic banking groups, actively use the ICM to isolate the rate of growth of loans in host countries from available local resources (measured by the rate of growth of local deposits). Both the analytical framework and the empirical analyses developed in this paper are consistent with the claim that the activities carried out by MNBs through their affliates have not been a source of financial instability in host economies. Rather, they have enhanced the supply of resources in those local markets.

Although it provides a general framework for analysis and evidence on worldwide trends in multinational banking, this paper focuses mostly on the European Union. Our results show that the ICM is particularly effective when banks operate within the integrated EU financial market. Thus is not surprising since retail activities and corporate lending and support to local businesses are non tradable, and in this domain, market integration can only be fostered through the activities of MNBs. To this extent the ICMs and the external capital market are to some degree complementary. When the external capital markets are less integrated, for regulations or because they involve different currencies, then the ICMs of MNBs are de facto operating to a very limited extent or even inactive, with no differences with respect to domestic banks. Consequently, even though some of the top multinational banks in the world are non European, the largest share of multinational banking activities are carried out within the European Union and by European banks.

\footnotetext{
${ }^{4}$ For example Ostry et al., 2010 have recently argued that FDI in the financial sector in emerging economies may be disguising a build up of intragroup debt in the financial sector and increase the riskiness of local financial systems.
} 
Within an integrated financial market there is a special urgency for reforming regulations and supervision, so as to deal with groups operating cross-border. Based on our analysis on the working of ICMs, we then discuss how a reformed European regulatory framework could enhance the stabilising role of MNBs and reduce the likelihood of systemic distress. We support the call for an integrated European supervision of MNBs and for an increased harmonisation of national regulatory frameworks.

European countries should contemplate a new and specific framework for European MNBs that would allow these banks to set-up truly integrated organizations with well functioning ICMs. This framework would define the responsibilities and the powers of the parent company and its foreign affiliates, providing due protections to minorities and creditors is granted. A specific treatment for MNBs in terms of regulation and supervision should be contemplated, along the lines of the proposals that have already been discussed in Europe (i.e., enhancing coordination among countries through strengthened colleges of supervisors overseen by a newly created European Banking Authority and also possibly defining rules for the allocation of the costs of rescuing those banks in case of distress). A sensible revision of the current framework should seriously keep into account the organizational format that MNBs adopt for their ICMs. And also that the effectiveness of any regulatory reform strictly depends on the level of financial integration between the countries where the bank is active.

Several other works have been looking at the functioning of the ICM for global corporations in general and specifically for banks (see for example Houston et al. 1997, Houston and James 1998, Morgan et al. 2004, Kroszner and Strahan 2006, de Haas and van Lelyveld 2010). These works are discussed in Sections 3 and 4. Also, a very large number of recent contributions have discussed regulatory and supervisory reforms to deal with MNBs (see for example Eisenbeis and Kaufman 2006, Dermine 2005, Frexias 2009). The novelty of this paper is combining the analytical insights on the functioning of the ICM with empirical evidence which compares the performance of MNBs to the one of standalone national banks. Also, this paper uses the latest available micro and macro data to examine how MNBs behaved during the recent crisis, a novelty in the economic literature to our knowledge.

The reminder of this paper is organized as follows. The next Section sets the scene and provides aggregate descriptive evidence on worldwide trends in multinational banking. Section 3 outlines an analytical framework for the functioning of the ICM, highlighting several testable implications on the conditions under which the "bright side" of ICMs (e.g., their ability to support affiliates in distress) is more likely to emerge and taking them to the data. Section 4 is devoted to the assessment of the effects of the crisis on the behaviour of MNBs with particular reference 
(although not only) to Europe. Finally, Section 5 concludes and develops some broad policy implications of our analysis that may be useful in particular for the current debate in Europe.

\section{Key facts on multinational banks}

This section examines the key facts of the main global trends in the activities of multinational banks since 2000, as emerging from aggregate statistics. It sets the scene for the subsequent analysis of the behaviour of these banks during the crisis. We examine how large these activities are with respect to the size of host countries' economies and how fast they have been growing in the last decade. In particular, we look at the patterns of the assets and liabilities of foreign affiliates, as these are the distinctive activities of MNBs, those likely to have a larger long term impact on the economies of the host countries. We defer to Section 4 the assessment of how these activities have been faring since the outset of the financial crisis.

Two key facts emerge from the data. First, total claims of foreign affiliates ${ }^{5}$ of banks have been rising worldwide, in absolute terms and with respect to the total banking assets and the GDP of host economies. Second, the rise has been especially large in the EU and particularly within the Euro area.

The rise of multinational banking. The activities of MNBs' affiliates in host countries differ from cross border financial transactions, that could also be undertaken by non multinational banks. These activities are mostly non tradable, as they include retail banking and loans towards local businesses. As argued by Mc Cauley, Mc Guire and von Peter (2010), international banking has evolved for many countries from a model essentially based on centralised patterns of resource allocation (involving a large share of cross border transactions), whereby headquarters pool funds and then reallocate them within the group, to a more decentralised pattern, where affiliates are allowed to raise funds locally to finance assets in each location. As we will discuss extensively in the next Section, both models of multinational banking can be more or less efficiently supported by an ICM channelling funds across countries within the group. However, the decentralised model implies that a larger share of funds is directly intermediated by foreign affiliates.

The increasing role of foreign affiliates in local markets indeed emerges from the aggregate cross-country statistics provided by the Bank for International Settlements' (BIS) Banking Statistics, discussed in details in Box 1. These statistics provide data on the claims of foreign affiliates in host countries vis à vis local residents (families, firms and other financial institutions) -

\footnotetext{
${ }^{5}$ See Box 1 for a definition.
} 
defined as local claims - denominated in local and foreign currency. ${ }^{6}$ These include loans, but also securities such as stocks and bonds. BIS statistics also provide data on total foreign claims, which include all the foreign assets held abroad by banks (domestic and multinationals), i.e., summing up the local claims held through local affiliates with those held through cross-border transactions.

\section{BOX 1: The Consolidated Banking Statistics of the Bank for International Settlements (BIS)}

- The BIS Banking Statistics report financial claims and liabilities of banks towards the rest of the world.

- Claims comprise financial assets (on balance sheet items only) including, as a minimum, deposits and balances with other banks, loans and advances to non-banks as well as banks, and holdings of debt securities. It excludes derivatives and off balance sheet transactions.

- Data are compiled on a consolidated (Consolidated Statistics) and on an unconsolidated basis (Locational Statistics).

- The Consolidated Statistics cover claims and liabilities reported by domestic bank headquarters, including the exposures of their foreign affiliates vis-à-vis individual host countries, and are collected on a consolidated basis by nationality of reporting bank and with inter-affiliate positions being netted out. The statistics also provide separate data on international claims of foreign affiliates whose headquarters are located outside the reporting countries on an unconsolidated basis (defined as "Local Claims", see below).

- The Locational Statistics cover international claims and liabilities by residence of the reporting banks, hence they include both domestic and foreign-owned affiliates in the reporting countries and on an unconsolidated basis, including those vis-à-vis own affiliates. As locational statistics combine foreign activities of both national and multinational banks, it is not possible to disentangle separate data belonging to foreign affiliates.

- From a risk reallocation perspective, BIS provides information either on an immediate borrower basis or on an ultimate risk basis. Within the former, the claim is allocated directly to the country of immediate risk; the latter reallocates claims to the country of ultimate risk which is defined as the country where the guarantor of a claim resides. The use of derivative transactions for instance often imply a mismatch between risk allocated on a borrower or on an ultimate risk basis: suppose an Italian bank acquires a bond issued by a German issuer but guaranteed by a US insurance company on the basis of a derivative transaction written on the top of the bond; in this case, Germany is the country of the immediate guarantor, while US the country where the ultimate risk resides.

- Most of the data used in Section 2 are derived from the Consolidated Statistics and expressed on an immediate borrower basis, as per the following definitions:

- Foreign Claims: defined as the sum of cross-border claims of domestic banks plus the local claims in all currencies of domestic banks' foreign affiliates. This category can be calculated as the sum of international claims $(\mathrm{A}+\mathrm{B})$ and local claims in local currency (C). For instance, these would include all the cross border claims of a multinational bank on a consolidated basis plus the local claims of its foreign affiliates vis-à-vis local residents.

- International Claims (A + B) are defined as banks' cross-border claims (A) plus local claims of foreign affiliates in foreign currencies (B).

\footnotetext{
${ }^{6}$ The BIS Banking Statistics reports separate statistics for local claims in local currency only, whereas local claims in foreign currency are summed up with cross border claims, and thus are not immediately identifiable. Following Mc Cauley, Mc Guire and von Peter (2010) they can be estimated starting from March 2005 as the difference between total international claims on an immediate borrower basis and cross border claims on an ultimate risk basis (further details and a discussion on the bias introduced by this estimation in Box 1).
} 
- Local Claims (C) refer to the claims denominated in local currency of foreign affiliates (branches and subsidiaries, see below for the distinction) on the residents of the host country (ie country of residence of affiliates).

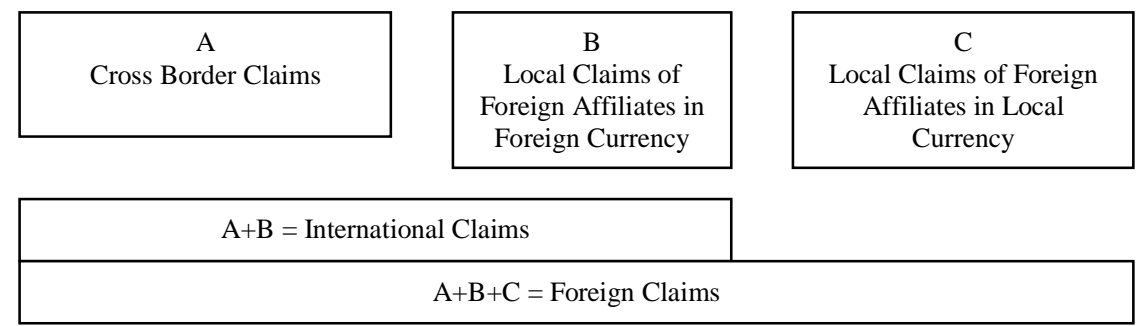

- Local Claims of foreign affiliates are the key variable used in the analysis of this paper, as it measures the claims of foreign affiliates towards residents in the host country. However, consolidated statistics on an immediate borrower basis provide separate data only on local claims in local currency and not on local claims in foreign currencies. Therefore, local claims in foreign currency are estimated as the difference between total international claims on an immediate borrower basis (table 9AA BIS Statistics) and cross border claims on an ultimate risk basis (9CT BIS Statistics). Estimates for local claims in foreign currency at the country level include therefore a bias which is higher the higher the ultimate transfer risk is.

- Local Liabilities refer to liabilities of foreign affiliates of domestic banks in local currency visà-vis local residents

Trends in local and foreign claims are reported in Figure 1A and 1B below. Local claims in local currency (measured in current US \$) rose in absolute terms to a value of more than 10 trillion dollars and almost doubled between 2000 and 2009 with respect to world GDP (from roughly 10\% to $20 \%$ ). Also local claims in foreign currency followed a similar pattern, although they can only be estimated as of March 2005. Both types of local claims summed up to more than 17 trillion dollars in 2009, accounting for more than 55\% of total foreign claims, also reported. Notice that in 2008 and 2009 total foreign claims experienced a more pronounced decline compared to local claims. We will further discuss this point in Section 4, which deals specifically with the crisis.

\section{Figure $1 \mathrm{~A}$ \\ Total Foreign and Local Claims in Nominal Values}

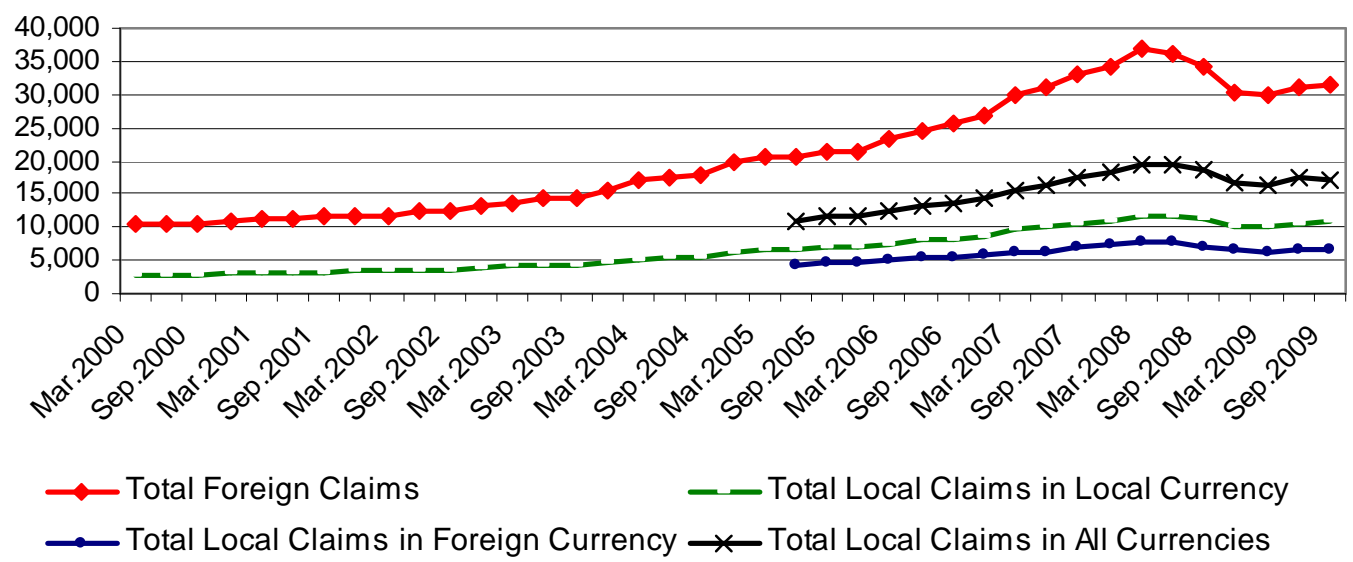


Figure 1 B

Total Foreign and Local Claims in \% of GDP

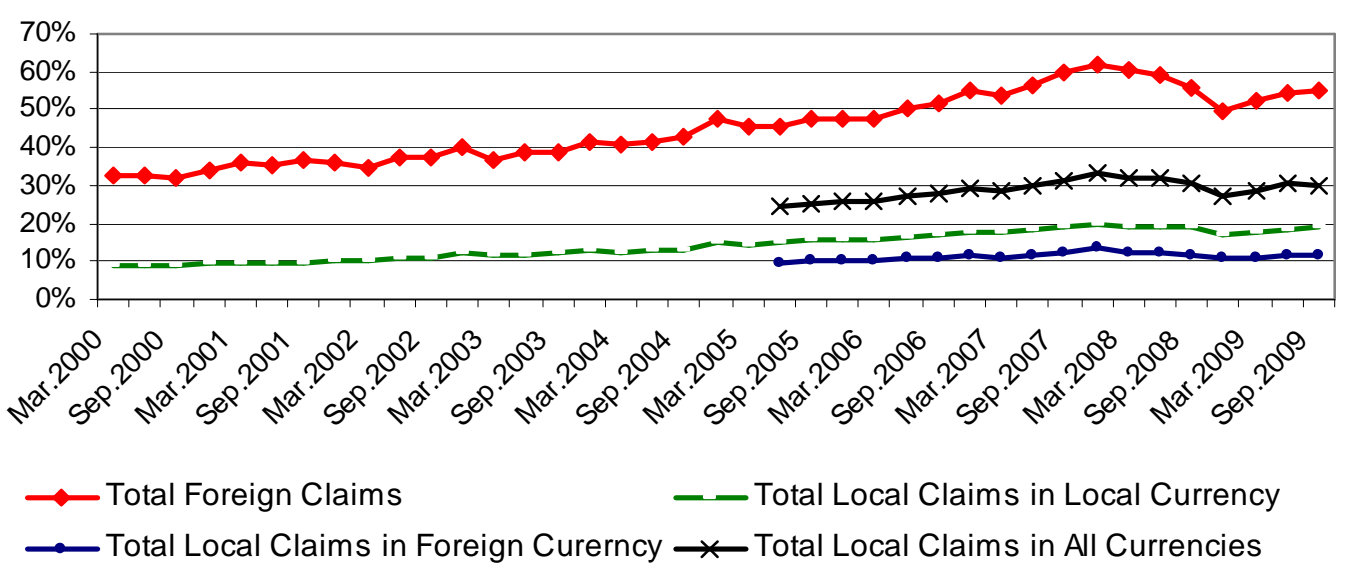

The rise of multinational banking has been especially fast within the $\mathrm{EU}$ single market. Decomposing the BIS data by regions of destination, we notice that the value of local claims of foreign affiliates denominated in local currency (converted in current US \$ in the BIS statistics) have been rising especially fast in the EU, particularly among the EMU 12 countries (Figure 2), reaching the other advanced economies, including US and Japan by the end of the period. ${ }^{7}$

\footnotetext{
${ }^{7}$ Here we restrict our analysis to claims denominated in local currency, as the bias in the estimates of those in foreign currency is particularly severe at the level of a country or a group of countries.
} 
Figure 2

Nominal Total Local Claims of Foreign Affiliates by Host Region

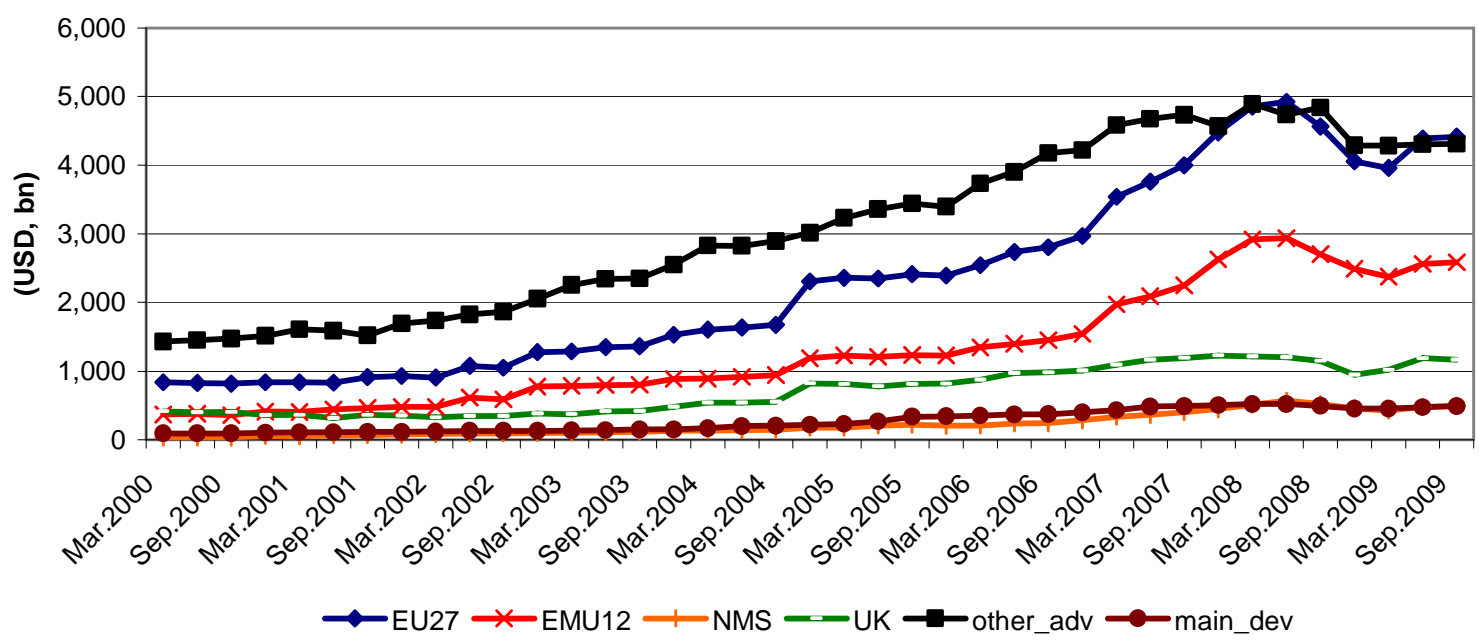

Source: BIS Consolidated Statistics

Note:

Other advanced: US, Canada, Japan, Australia, New Zealand, Switzerland

NMS: Bulgaria, Cyprus, Czech Republic, Hungary, Latvia, Lithuania, Malta, Poland, Romania, Slovak, Slovenia

Main developing: China, India, Malaysia, South Korea, South Africa, Singapore, United Arab Emirates

These trends are also the outcome of severe exchange rate fluctuations in the period analysed. The yen roughly devalued by $30 \%$ with respect to the Euro between 2000 and 2009 and the dollar by almost 50\%. To better gauge the increasing role of multinational banking it is therefore necessary to relate local claims to the value of total banking assets in the countries of destination. This is done in Table 1.

The especially important role of foreign affiliates in the EU stands out clearly when the size of their assets is normalised with the total banking assets of each country. By mid 2009 these were $16.9 \%$ with respect to total assets, compared to a mere $5.9 \%$ for the other industrialised economies. The ratio for the EU has also risen considerably (and at a faster pace than for other advanced economies) from the early 2000 , when it was lower than $10 \%$. The picture is pretty heterogeneous within the Union. Foreign affiliates have an especially large role in the UK and in the new member states (NMS), particularly in those that have adopted the Euro, where they account for a very large share of total assets. These particularly high shares reflect of course the role of the UK as an international financial center and, for the NMS, their relatively weak local financial institutions which were acquired by large European banks during the transition years. As for the EMU 12, the share of assets held by foreign banks is lower than for the EU average. However, given the size of this area, in nominal values the EMU 12 countries account collectively for the largest amount of local claims held by foreign affiliates. 
The evidence that MNBs have become increasingly active within the EU, particularly through mergers and acquisitions, requires some qualifications. ${ }^{8}$ We will discuss extensively this result also in Sections 3 and 4. In principle, an integrated financial market should provide an ideal ground for cross border market transactions, reducing the need to rely on the ICM to move resources across countries, as it would be the case with MNBs. Yet, we know that retail activities are non tradable even within integrated markets. Therefore, tapping the European retail market requires having local operations in foreign countries anyway. But within an integrated financial area and particularly with a single currency, those local operations can likely benefit from easier and smoother intra-bank cross border transactions, taking place through the ICM.

Table 1: Total Local Claims in Local Currency on Total Assets

\begin{tabular}{l|rrrrrrrrr} 
& avg 2001-2003 & avg 2004-2006 & 2007 & 2008-I & 2008-II & 2008-III & 2008-IV & 2009-I & 2009-II \\
\hline EU27 & $9,8 \%$ & $13,3 \%$ & $17,9 \%$ & $17,8 \%$ & $17,7 \%$ & $17,8 \%$ & $16,4 \%$ & $16,6 \%$ & $16,9 \%$ \\
EMU12 & $7,5 \%$ & $9,9 \%$ & $15,1 \%$ & $15,4 \%$ & $15,2 \%$ & $15,2 \%$ & $14,1 \%$ & $13,8 \%$ & $13,8 \%$ \\
UK & $16,5 \%$ & $21,7 \%$ & $23,0 \%$ & $21,7 \%$ & $21,3 \%$ & $21,5 \%$ & $21,0 \%$ & $22,9 \%$ & $23,4 \%$ \\
NMS & $35,7 \%$ & $43,1 \%$ & $50,2 \%$ & $49,4 \%$ & $50,6 \%$ & $48,9 \%$ & $44,7 \%$ & $46,6 \%$ & $47,4 \%$ \\
other_adv & $4,1 \%$ & $5,1 \%$ & $6,0 \%$ & $6,3 \%$ & $6,0 \%$ & $6,3 \%$ & $5,6 \%$ & $5,9 \%$ & $5,9 \%$
\end{tabular}

Source: BIS Consolidated Statistics for Local Claims in Local Currency. IMF, International financial Statistics for Total assets Note: $\quad$ - Other advanced: US, Canada, Japan, Australia, New Zealand, Switzerland

- NMS: Bulgaria, Cyprus, Czech Republic, Hungary, Latvia, Lithuania, Malta, Poland, Romania, Slovak, Slovenia

- Main developing: China, India, Malaysia, South Korea, South Africa, Singapore, United Arab Emirates

The argument that the ICM is likely to work more smoothly within integrated financial areas is also supported by the evidence that most foreign banking activity in the Union is intra-European. This can be gauged by ECB data, where total banking assets of member countries are decomposed by the nationality of ownership of the bank $^{9}$ and by whether foreign affiliates are independent subsidiaries or branches. As we will further discuss below, the distinction between subsidiaries and branches is important both from the point of view of the organisation of the internal capital market

\footnotetext{
${ }^{8}$ M\&A activity within the EU banking sector experienced a boom at the beginning of the new century. In 2000 there were approximately $140 \mathrm{M} \& \mathrm{~A}$ transactions in EU, of which intra EU $25 \mathrm{M} \& \mathrm{~A}$ deals involving a non domestic acquirer represented almost $30 \%$ of the total.

${ }^{9}$ Assets of credit institutions under the ECB definition comprise any asset that is (i) cash; or (ii) a contractual right to receive cash or another financial instrument from another enterprise; or (iii) a contractual right to exchange financial instruments with another enterprise under conditions that are potentially favourable; or (iv) an equity instrument of another enterprise. Total assets are calculated on a residential basis, meaning that for each Member State the credit institutions under the law of that Member State are included (regardless of whether or not they are a subsidiary of a foreign bank). However, the activity of the foreign branches of these credit institutions is not included, as this is reported by the host country. Credit institutions include any institution covered by the definition contained in Article 4(1) of Directive 2006/48/EC (recast). Accordingly, a credit institution is "(i) an undertaking whose business is to receive deposits or other repayable funds from the public and to grant credits for its own account; or (ii) an electronic money institution within the meaning of Directive 2000/46/EC. The most common types of credit institutions are banks and savings banks".
} 
and of the regulatory framework in the EU (see Calzolari and Loranth 2005 for an analysis of regulation of MNBs in terms of their organization). ${ }^{10}$ This decomposition is reported in Figure 3. Differences in definitions of asset categories explain why the ECB figures do not match precisely the BIS figures reported above. ${ }^{11}$

Figure 3

Distribution of Total Banking Assets EU 27 (2008)

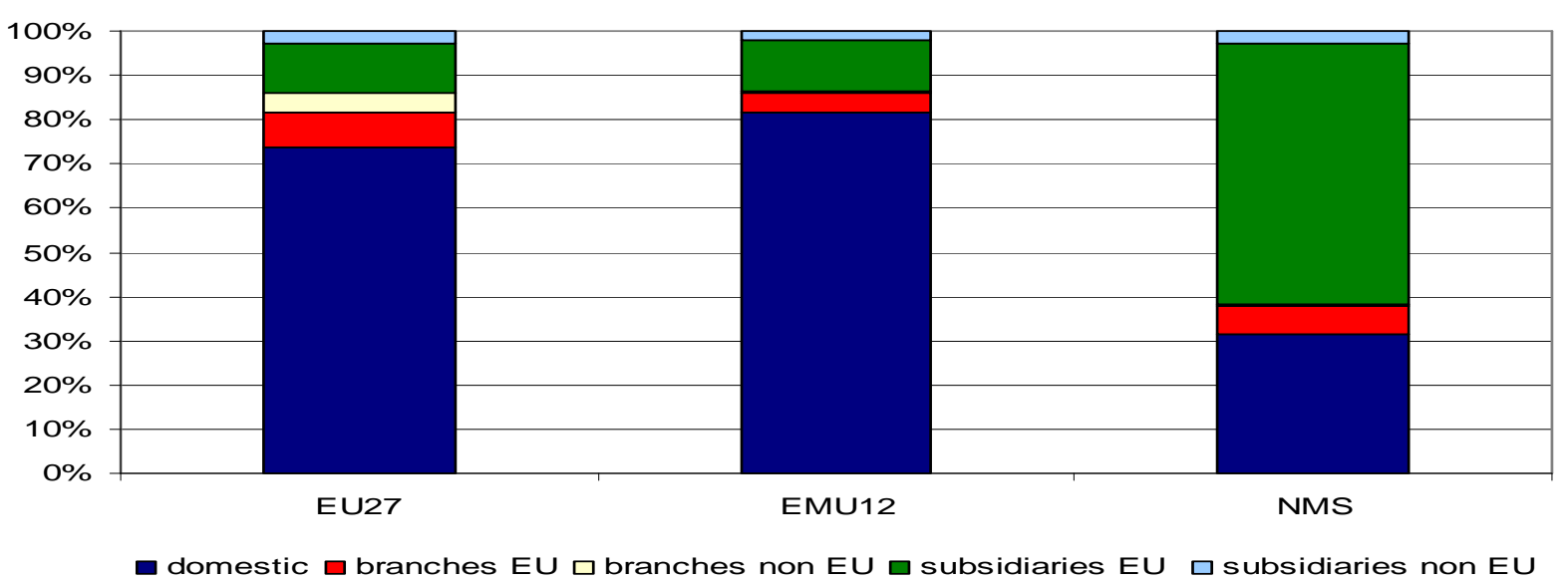

Source: ECB Statistics

Note: NMS: Bulgaria, Cyprus, Czech Republic, Hungary, Latvia, Lithuania, Malta, Poland,

Romania, Slovak, Slovenia

If we consider the aggregate of the EU countries, we notice that foreign banks account for roughly $29 \%$ of total assets, held through either subsidiaries or branches. Foreign banks' assets can further be decomposed into EU and extra-EU institutions. Notice that by far the largest share of these assets are owned by EU banks. This share is especially large within the EMU aggregate.

The EU is therefore an especially interesting case to look at for assessing the role of MNBs and the functioning of their ICMs, particularly during the financial crisis. This justifies our focus on the EU in the micro analysis of the following Sections.

\footnotetext{
${ }^{10}$ Subsidiaries are stand alone companies, where local management has a high degree of decisional autonomy within the group. In the current European regulatory framework they are subject to host country supervisory authorities. Branches are part of the foreign group and not stand alone companies, normally with less decisional autonomy than subsidiaries. They are subject to the home country supervisory authorities. Branches are used more frequently by multinational banks to carry out wholesale activities. Subsidiaries are normally used to carry out retail activities, given that they collect deposits and that a large part of their transactions have to be carried out face to face with local customers. The largest share of foreign assets is held by EU banks through subsidiaries. This reflects the recent spur of cross-border acquisitions, where acquired banks become autonomous foreign subsidiaries and also the fact that within Europe foreign affiliates are generally used to carry out non tradable activities like retail.

${ }^{11}$ Note that the share of the assets held by foreign banks $(29 \%)$ is larger than the share of local claims on total assets $(14.71 \%)$ and smaller than the share of foreign claims $(60.31 \%)$ reported in table $1 \mathrm{~A}$ and $1 \mathrm{~B}$. The reason is that the definitions of assets are different for the two institutions. Foreign assets under the ECB include claims towards residents and non residents in the host country held by foreign subsidiaries and branches based in a given EU host country (but not those held through other foreign subsidiaries or branches based abroad). Local claims under the BIS has a strictly host country perspective and only includes claims of foreign branches and subsidiaries vis a vis residents in the host country. Foreign claims in BIS statistics also include cross-border transactions.
} 
3 Multinational banks and internal capital markets: implication for efficiency and financial stability

This section examines how the availability of an internal capital market (ICM) affects the behaviour of MNBs, and their possible reactions during a crisis. It is indeed the ICM that makes the activities of foreign affiliates in host economies distinctly different from those of standing alone national banks. Large corporations can establish ICMs that allocate scarce capital, liquidity and risk across the many units belonging to the holding (Box 1 below briefly describes the functioning of ICMs and summarizes the literature in finance and economics that have analyzed their working, both theoretically and empirically).

This analysis is important to our aims since multinational banks (MNBs) have the possibility to diversify risk internationally, to optimally allocate funds across their network of international affiliates in search of higher returns, and to efficiently share liquidity. We are also particularly interested in understanding whether ICMs in cross-border banks have stabilizing or destabilizing effects in home and host countries, in normal times and in times of crisis. In particular, as for the effects of shocks affecting banks and host countries, in this Section we will deal with idiosyncratic ones, whilst the next Section will be devoted to the systemic shocks of the present crisis. We will develop a theoretical framework for MNBs and their ICMs which will deliver a number of "claims". Considering the set of all these claims we will then derive some testable implications that will be explicitly verified with the empirical analysis in the next Section.

\section{BOX 2: Internal Capital Markets (ICMs): the Bright and the Dark Side}

Financial and non-financial institutions are often organized in divisions or affiliated units, by product or by location. Consider, for example, a bank with its parent company $\mathrm{P}$ and two affiliates A1 and A2, each with some internal funding, collaterals, pledgeable income and investment opportunities (see the next Figure for a graphical representation). A1 can be financed as a stand-alone entity using funds internal to A1 or raised directly by A1 in the external credit market. Alternatively, in the absence of constraining regulation, A1 can be financed in an ICM in which A1 approaches $\mathrm{P}$ for funding. The parent $\mathrm{P}$ in turn can directly raise external funds against its own and the combined collateral of affiliates A1 and A2, centralize the funds individually raised by the affiliates and, finally, allocate them to A1, A2 and $\mathrm{P}$ according to some criteria. In the end, this allocation is similar to the task performed by the credit market, although it takes place within the "internal" capital market of the bank. The central question for ICMs is whether this internal process is more or less efficient and profitable for the bank than an external market for credit. Clearly, if the capital market were fully efficient, ICMs would be irrelevant, but we know this is almost never the case. First, raising external funds in a centralized way may allow to increase the total amount of funds (the "more-money effect" of ICMs). Second, funds may be allocated more efficiently and profitably to all investment opportunities when the process is centralized and information asymmetries are overcome (the "smarter-money effect" of ICMs). Clearly the two effects, which are known as the "bright side" of ICMs, are related (smarter money may lead to more money) and depend on ICM's organization, as shown by a significant theoretical and 
empirical academic literature. ${ }^{12}$ In particular, more-money may takes place since control power attributed to the internal capital market should induce more screening and monitoring of the projects to be financed. Furthermore, an ICM may create value in financially constrained firms, since affiliates' projects compete for scarce internal funds and are jointly screened within the ICM. However, badly organized ICMs may show up with a "dark side": competition for funding may turn out to be wasteful rent-seeking, funds may be spread among affiliates with no reference to relative merit, thus dampening incentives and with affiliates' manager feeling expropriated. The empirical literature has shown that ICMs do operate in large corporations since one observes that shocks in one affiliate affect investments in other affiliates and investments in small units are positively related to cash flow of other units. ICMs have been also shown to deliver more and smarter money when the external capital market is less developed (e.g. for weak legal enforcement, inadequate accounting and disclosure practices); when divisions have not sharply divergent investment prospects; when the firm is able to control the agency issues intrinsic to ICMs using high powered incentives such as management ownership. The literature on ICMs for banks is instead less developed and that on MNBs even less so, as discussed in the main text.

Affiliates of a multinational bank (MNB henceforth) bank located in different countries may well face different costs of external funds. These banks may thus collect deposits, say in country 1 and 2 , and finance a project in country 2 by pooling deposits in an ICM. In addition, by pooling liquidity from affiliates in different countries, when affiliates' liquidity shocks are not positively correlated, an MNB bank may then be able to keep lower liquidity to take care of the duration mismatch of assets and liabilities typical of the transformation activity of banks. For given regulatory constraints that national authorities impose to banks on liquidity, this possibility allows an MNB to reduce overall costs. Although diversification can also be obtained in a large national group, it is clear that cross-border activities may well increase diversification. On the other hand, one should also consider that the functioning of an ICM operating across countries may be hindered by factors such as limited economic and regulatory integration, differences in (business) culture, in languages and by distance among the units belonging to the ICM, as we will further illustrate.

From these arguments it is possible to derive some important consequences of an ICM in a banking group and, in particular, for an MNB. As explained in Box 2, the organization of an ICM and its functioning are responsible for the possible realization of "smarter money", according to which funds, risk and liquidity are allocated to the MNB's affiliates that are better at managing them. This process of relocation leads to a support effect and a substitution effect which are described next (this useful taxonomy is due to Morgan et al. 2004).

12 Some relevant theoretical papers are Williamson (1975) and Gertner et al. (1994) have shown that Stein (1997) and (2002) illustrates that (Scharfstein and Stein 2000, Rajan et al. 2000), (Hart and Holmstrom 2002 Brusco and Panunzi 2005); for empirical analysis see among others Lamont (1997), Scharfstein (1998), Shin and Stulz (1998), Rajan et al. (2000), Whited (2001), Chevalier (2000), Ozbas and Scharfstein (2008), Khanna and Tice (2001), Billet and Mauer (2003). 


\section{Figure 4: Functioning of ICM of an MNB when affiliate A1 is hit by shock on capital}

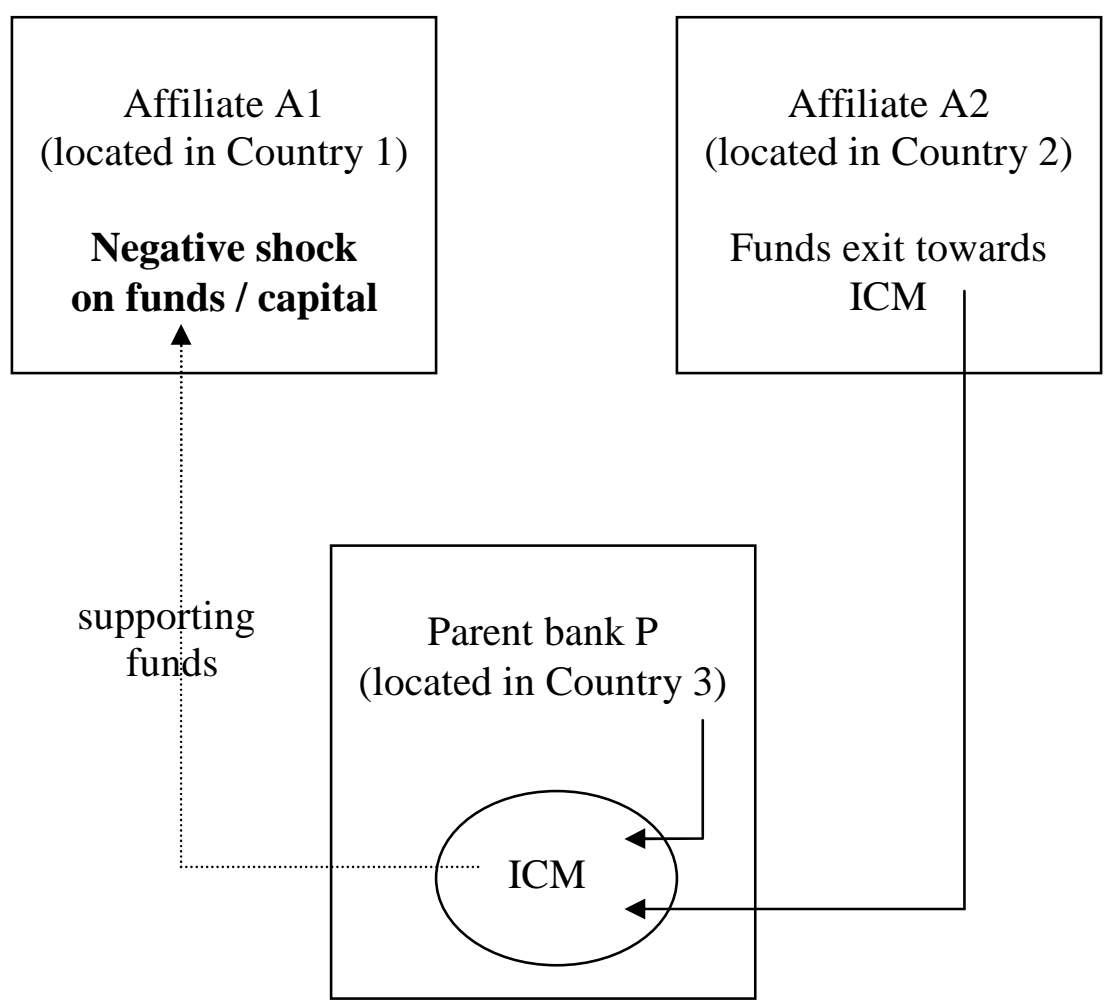

Consider Figure 4 and a shock that is local in country 1 deteriorating capital (assets or loans) or reducing funds availability (with a reduction of deposits) of affiliate A1 of the MNB. This negative shock may force the affiliate either to obtain new equity, to satisfy its capital adequacy ratio and/or its strategies, or to reduce its loans. This would certainly be the case were the bank a single entity. When belonging to an $\mathrm{MNB}$, instead, the shock may be reduced by capital and liquidity supported by home or other affiliates in foreign countries, through the ICM. An MNB may then be able and willing to support its affiliates in cases of country-specific shocks, thus watering down the effect of these local shocks: the support effect makes an affiliate's lending capacity less responsive to local shocks on capital and deposits, i.e. on the availability of local funds (Claim 1).

In addition to the support effect, an ICM determines capital and liquidity movements looking for the best remuneration within the MNB (the "smarter money"), that might lead to a substitution effect. Consider now a real shock hitting the economy in the country of an affiliate (say country 1 in the previous figure), thus reducing the returns of investments in that country. Then, the ICM would substitute the activities of that affiliate relocating funds towards the parent bank and other affiliates with better investment opportunities. This makes an affiliate's lending in a banking group more responsive to shocks affecting the returns of its investments. Hence, the substitution effect weakens the link between funds availability and lending. This is more so for 
banking groups operating in countries with little correlated real shocks and it is definitely less relevant for domestic banking groups operating in a single country. (Claim 2).

The support and substitution effects emerge from the "smarter money" of an ICM. We are now interested to see the role of "more money" that a banking group may generate if its ICM works properly (see again Box 2). If this is the case, then an ICM has much more information and control on a troubled affiliate than the external capital market which, instead, may be completely impaired due to lack of information. On a similar vein, the functioning and the effects of ICMs are closely related to the organization and the incentives that are used in setting up an MNB's ICM. On the one hand, affiliates may be tightly integrated to form a unique ICM, such as for branches of a bank which are de facto (and de jure) parts of the holding company. Alternatively, even though they take part in an ICM, affiliates may keep some independence and responsibility in their decisions, as it is often the case for MNBs' subsidiaries (which are de jure independent legal entities controlled by the holding). We are mainly interested in the organization of groups with subsidiaries, which are the predominant form of foreign affiliates in Europe (with the exception of the UK), also because, as explained in the sequel, data on single affiliates are only available for subsidiaries. It has been emphasized (Shah and Tahkor 1986, Kahn and Winton 2004, Boot and Schmeits 2000) that a subsidiary structure may allow external investors to better evaluate the different projects in the holding by clearly associating projects to single units so that higher transparency translates into smaller cost for external funding. Hence, a well organized ICM of domestic and international banking groups may generate "more money" available to address any kind of shock, thus smoothening the link between funds and lending (Claim 3).

Overall Claims 1-3 all point to a reduction of correlation between available funds and bank's lending capacity.

As explained in Box 2, however, an ICM can deliver its desirable properties that lead to Claims 1-3 when showing its bright side. Support/substitution are strictly related to the information that is made available within the organization, since an ICM involves a decision process that requires information. ${ }^{13}$ Hence, a more integrated ICM with intense information sharing may lead to more substitution and support effects. However, for an ICM to work smoothly, there must not be impediments which can emerge as external constraints. These constraints may emerge because of an inadequate organization and incentive mechanism of the ICM, but also by the regulatory and economic environment. Pooling resources into an ICM and relocating internationally to the affiliate

\footnotetext{
${ }^{13}$ A decentralized MNB with more independent units still belonging to the ICM (i.e. a flatter organization) is most likely to be an attractive option when information about individual projects is "soft" and cannot be easily and credibly transmitted upstream through the hierarchy. In contrast, a large and hierarchical MNB with multiple layers composed of units of limited independence and a strongly integrated ICM is best when information can be "hardened" and passed along the hierarchy.
} 
in need of support requires that the MNB satisfies a set of rules imposed by possibly many different countries (since a fully harmonized or integrated regulatory authority is still missing in the international banking sector) thus leading to a "regulatory risk". Pooling resources also exposes the MNB to a "transfer risk", for example associated with the exchange rate swings of the currencies in use in the different countries. On a similar vein, the literature on the ICM has shown that this should operate better when the participating units have not sharply divergent investment prospects as it is the case in related economies. Thus MBNs operating in an integrated area, both in terms of regulations and in terms of currencies, may make a more intense use of their ICMs (Claim 4). Furthermore, one may expect that units that are located in distant countries with different languages or different cultural environments may find it difficult to actively take part into a crossborder ICM of an MNB (Claim 5).

In light of Claims 2, 4 and 5, it will be particularly interesting to understand whether the ICMs are substitutes or complements of the process of market integration taking place at different stages in Europe. On the one hand, as illustrated above, the need of an ICM may be limited in very well integrated economies with correlated real shocks, since the external and the integrated internal capital markets may function as substitutes. On the other hand, differences in terms of cultures, languages, banks' regulations and currencies may obstacle the kind of integration within the MNB that is needed for an ICM to work smoothly.

That ICMs operate in large banks is a documented fact. It has been shown that loan growth of an affiliate of domestic holdings is more sensitive to the parent's cash flow and capital than the affiliate's own capital (Houston et al. 1997, Houston and James 1998, Morgan et al. 2004 and Kroszner and Strahan 2006). As for cross-border banks, de Haas and van Lelyveld (2010) have documented the functioning of ICMs in top 45 MNBs around the world (see also Chan-Lau et al. 2008), showing that they are more active (in terms of support and substitution effects) in foreign units that are less independent (e.g. that have been established with green field investment instead of takeover). ${ }^{14}$ In this case the substitution effects is at play, since they show that foreign lending is negatively related to the business cycle of the home country of the parent holding and they also show that the support effect shows up mainly for dependent units of MNBs that reduce lending less than independent banks. ${ }^{15}$

\footnotetext{
${ }^{14}$ Havrylchyk and Jurzyk (2006) show that greenfield banks are much more embedded in a multinational bank group's internal capital market, whereas acquired banks within the group seem to be organized as rather independent capital centers.

${ }^{15}$ On anecdotal evidence, during the 2003 crisis of Norvegian banks, it has been observed that Noredea Norway, although hit by significant losses (accounting for 1,17\% of its gross lending in 2003), was able to limit the reduction of its capital by borrowing from the Nordea Group. Looking at the crisis of Japanese banks in the early 1990s, units in the US experienced reduction of lending in case they were units more dependent from the parent banks but they were almost unaffected when they were more independent.
} 


\subsection{Empirical evidence on the functioning of internal capital markets: an European perspective}

Following the five claims we identified above, we now turn to an empirical analysis of the effects of ICMs on the link between bank lending and funds availability in Europe. To do so, we consider how, in a given bank, deposits co-vary with loans, focusing therefore on one specific effect of the availability of an ICM, its impact on the correlation between funding and the use of resources. The advantage of using this simple index is that it requires no assumptions on the direction of causality between deposit and loan growth. We focus instead on the possible differences in their correlation between banks that do have internal capital markets and banks that do not. Clearly, this exercise is only possible by retaining a control group of standalone units, that represents our benchmark for banks that have no access to ICMs.

The existing empirical literature has not explicitly considered domestic banks and domestic banking groups as controls for a direct comparison for the effects of national and international ICMs. Our strategy is therefore complementary to that of de Haas and van Lelyveld (2010), who show that the lending behavior of bank affiliates is affected by their parents' financial conditions, but only control for the contemporaneous behavior of very large standalone units, that might not be fully comparable with typically smaller foreign affiliates.

Comparing the correlation between loans and deposit of MNBs and a counterfactual of national banks is also justified by the fact that we are focusing our analysis on Europe, where the number of country specific crises is very limited. Consequently, in our case, contrary to de Haas and van Lelyveld (2010), we cannot test for the existence of the ICM by looking at how national banking crises affect the lending strategies of affiliates based in other countries. ${ }^{16}$

Finally, since we will concentrate on banks operating in Europe, we have the possibility to consider banks active in an economic area with a significant level of integration both for the real economies, thus being characterized by correlated real shocks, and for the financial sector. We will then study the interplay between international integration and the functioning of ICMs. As explained above, a priori the relationship could be one of complements or substitutes. Discriminating between the two cases is critical in particular in the current period of revision of the European environment for supervision and regulation of MNBs.

Our analysis is based on balance sheet information of a large sample of European banks, collected by the commercial data provider Bureau Van Dijk, in its Bankscope data base. We started by considering all affiliates in the EU27 countries of the 100 largest European banks (that are likely to be those that will be more directly supervised by European colleges of supervisors) between 2000

\footnotetext{
${ }^{16}$ According to the most reliable and updated dataset on banking crisis by Laeven and Valencia (2008) - the one used for example in de Haas and van Lelyveld 2010 - there are no national crisis in our sample, except for the global crisis hitting UK in 2007 which is however the first year of a global crisis.
} 
and 2008, distinguishing between domestic and foreign affiliates on the basis of their ownership structure. ${ }^{17}$ In addition, we have checked the shareholding structure of all other banks in our sample, that includes all institutions in EU27 countries with total assets above 100 US\$ million, to identify additional affiliates of domestic or foreign institutions. Summary statistics for our sample are presented in Table 2.

\section{Table 2: Summary statistics}

Data are from Bankscope

\begin{tabular}{|c|c|c|c|c|}
\hline \multirow[t]{2}{*}{ Variables } & Observations & Mean & Coeff. of variation & \multirow[t]{2}{*}{ Median } \\
\hline & \multicolumn{3}{|c|}{ Full sample } & \\
\hline Total assets (US\$ bn.) & 7,321 & 17.00 & 5.77 & 0.79 \\
\hline Customer loans $(\Delta \%)$ & 6,732 & 0.20 & 1.61 & 0.18 \\
\hline Demand deposits $(\Delta \%)$ & 5,915 & 0.20 & 1.86 & 0.20 \\
\hline Bank total assets - Country $(\Delta \%)$ & 9,236 & 0.17 & 0.43 & 0.18 \\
\hline Returns on assets (\%) & 7,306 & 0.58 & 4.06 & 0.47 \\
\hline Customer loans / total assets & 7,258 & 0.58 & 0.38 & 0.62 \\
\hline Bank deposits / total assets & 7,053 & 0.18 & 1.08 & 0.12 \\
\hline Equity / total assets (\%) & 7,311 & 10.28 & 1.51 & 7.27 \\
\hline Loan loss prov. / Net int. margin & 7,306 & 0.58 & 4.06 & 0.47 \\
\hline Net interest margin (\%) & 6,858 & 0.17 & 4.91 & 0.14 \\
\hline \multirow[t]{2}{*}{$\operatorname{GDP}(\Delta \%)$} & 7,196 & 2.85 & 1.99 & 2.70 \\
\hline & \multicolumn{4}{|c|}{ Affiliates } \\
\hline Total assets & 636 & 30.70 & 4.31 & 3.29 \\
\hline Customer loans $(\Delta \%)$ & 574 & 0.25 & 1.23 & 0.25 \\
\hline Demand deposits $(\Delta \%)$ & 499 & 0.22 & 2.30 & 0.21 \\
\hline Bank total assets - Country $(\Delta \%)$ & 632 & 0.24 & 0.49 & 0.22 \\
\hline Returns on assets (\%) & 633 & 0.71 & 2.84 & 0.69 \\
\hline Customer loans / total assets & 629 & 0.51 & 0.50 & 0.54 \\
\hline Bank deposits / total assets & 620 & 0.29 & 0.79 & 0.23 \\
\hline Equity / total assets (\%) & 636 & 10.48 & 0.96 & 7.62 \\
\hline Loan loss prov. / Net int. margin & 633 & 0.71 & 2.84 & 0.69 \\
\hline \multirow[t]{2}{*}{ Net interest margin $(\%)$} & 573 & 0.17 & 1.99 & 0.12 \\
\hline & \multicolumn{4}{|c|}{ Parent banks } \\
\hline Total assets & 207 & 208.00 & 1.99 & 38.90 \\
\hline Customer loans $(\Delta \%)$ & 188 & 0.17 & 1.08 & 0.18 \\
\hline Demand deposits $(\Delta \%)$ & 177 & 0.14 & 1.89 & 0.15 \\
\hline Bank total assets - Country $(\Delta \%)$ & 215 & 0.19 & 0.56 & 0.18 \\
\hline Returns on assets (\%) & 207 & 0.69 & 1.12 & 0.57 \\
\hline Customer loans / total assets & 207 & 0.54 & 0.40 & 0.57 \\
\hline Bank deposits / total assets & 205 & 0.20 & 0.83 & 0.15 \\
\hline Equity / total assets (\%) & 207 & 7.11 & 0.93 & 5.87 \\
\hline Loan loss prov. / Net int. margin & 207 & 0.69 & 1.12 & 0.57 \\
\hline Net interest margin (\%) & 205 & 0.16 & 1.09 & 0.15 \\
\hline
\end{tabular}

\footnotetext{
${ }^{17}$ As it is common in this literature, we have not been able to extend our analysis to the behavior of foreign branches, because with very few exceptions their activities are recorded only in confidential supervisory data, and not by all countries.
} 
Bank total assets - Country $(\Delta \%)$

Returns on assets (\%)

Customer loans / total assets

Bank deposits / total assets

Loan loss prov. / Net int. margin

0.29

10.67

Total assets

Foreign parent banks

Customer loans $(\Delta \%)$

Demand deposits $(\Delta \%)$

Bank total assets - Country $(\Delta \%)$

Returns on assets (\%)

Customer loans / total assets

Bank deposits / total assets

Equity / total assets (\%)

Loan loss prov. / Net int. margin

Net interest margin (\%)

Total assets

Customer loans $(\Delta \%)$

Demand deposits $(\Delta \%)$

Bank total assets - Country $(\Delta \%)$

Returns on assets (\%)

Customer loans / total assets

Bank deposits / total assets

Equity / total assets (\%)

Loan loss prov. / Net int. margin 61.00

0.12

53.30

0.17

0.13

0.14

$\begin{array}{lll}0.18 & 0.59 & 0.18\end{array}$

$\begin{array}{lll}0.69 & 1.12 & 0.54\end{array}$

$\begin{array}{lll}0.51 & 0.41 & 0.53\end{array}$

$\begin{array}{lll}0.22 & 0.77 & 0.17\end{array}$

$\begin{array}{lll}6.72 & 1.02 & 5.32\end{array}$

$\begin{array}{lll}0.69 & 1.12 & 0.54\end{array}$

$0.16 \quad 0.98 \quad 0.15$

Banks chartered in EMU

$\begin{array}{lll}15.30 & 6.05 & 0.74\end{array}$

$\begin{array}{lll}0.19 & 1.58 & 0.18\end{array}$

$\begin{array}{lll}0.20 & 1.79 & 0.20\end{array}$

$\begin{array}{lll}0.16 & 0.34 & 0.18\end{array}$

$\begin{array}{lll}0.53 & 3.83 & 0.43\end{array}$

$\begin{array}{lll}0.58 & 0.37 & 0.62\end{array}$

$\begin{array}{lll}0.18 & 1.08 & 0.12\end{array}$

$\begin{array}{lll}10.07 & 1.13 & 6.96\end{array}$

$\begin{array}{lll}0.53 & 3.83 & 0.43\end{array}$

Net interest margin (\%) $\quad 5,824$

Total assets

Banks chartered in EU15

Customer loans $(\Delta \%)$

Demand deposits $(\Delta \%) \quad 5,534$

Bank total assets - Country $(\Delta \%) \quad 8,650$

Returns on assets (\%)

Customer loans / total assets

Bank deposits / total assets

Equity / total assets (\%)

Loan loss prov. / Net int. margin

Net interest margin (\%)

18.00

5.93

0.15

0.78

$\begin{array}{lll}0.19 & 1.66 & 0.18\end{array}$

$\begin{array}{lll}0.20 & 1.82 & 0.19\end{array}$

$\begin{array}{lll}0.16 & 0.34 & 0.18\end{array}$

$\begin{array}{lll}0.58 & 3.59 & 0.45\end{array}$

$\begin{array}{lll}0.58 & 0.38 & 0.63\end{array}$

$\begin{array}{lll}0.18 & 1.09 & 0.12\end{array}$

$\begin{array}{lll}10.11 & 1.57 & 7.04\end{array}$

$\begin{array}{lll}0.58 & 3.59 & 0.45\end{array}$

$0.17 \quad 4.99 \quad 0.14$

Total assets

Foreign subsidiaries in EMU

32.10

$4.41 \quad 5.47$
1.48

Customer loans $(\Delta \%)$

Demand deposits $(\Delta \%)$

Bank total assets - Country $(\Delta \%)$

0.22

0.22

$\begin{array}{lll}0.20 & 2.97 & 0.20\end{array}$

$\begin{array}{lll}0.20 & 0.47 & 0.20\end{array}$

$\begin{array}{lll}0.49 & 2.86 & 0.53\end{array}$

$\begin{array}{lll}0.48 & 0.58 & 0.50\end{array}$

$\begin{array}{lll}0.33 & 0.75 & 0.28\end{array}$

$8.90 \quad 1.14 \quad 5.92$

$\begin{array}{lll}0.49 & 2.86 & 0.53\end{array}$

$0.19 \quad 2.29 \quad 0.13$

Loan loss prov. / Net int. margin $\quad 281$

Total assets

Foreign subsidiaries in EU15

$\begin{array}{lll}31.80 & 4.26 & 5.25\end{array}$

Demand deposits $(\Delta \%)$

Bank total assets - Country $(\Delta \%)$

Returns on assets $(\%)$

Customer loans / total assets

Bank deposits / total assets

Equity / total assets (\%)

Loan loss prov. / Net int. margin

31.80

4.26
1.51
3.17

0.20

$\begin{array}{lll}0.18 & 3.17 & 0.19\end{array}$

$\begin{array}{lll}0.19 & 0.49 & 0.19\end{array}$

$\begin{array}{lll}0.53 & 2.57 & 0.56\end{array}$

$\begin{array}{lll}0.47 & 0.60 & 0.48\end{array}$

$\begin{array}{lll}0.33 & 0.75 & 0.28\end{array}$

$\begin{array}{lll}9.46 & 1.16 & 6.03\end{array}$

$\begin{array}{lll}0.53 & 2.57 & 0.56\end{array}$

Net interest margin $(\%)$

0.18

2.36 
We have 9,236 banks, 645 affiliates of which 529 foreign, 218 parent banks of which 163 multinationals. ${ }^{18}$ The average size of the banks in our sample, measured by their total assets, is 17 US\$ billions, while the median is less than 1 US\$ billion, suggesting a significant left skewness, as it is quite common when using company data. Affiliates and parent banks are larger (30.7 US\$ billions and 208.0 US\$ billions, respectively). The average yearly rate of growth of nominal customer loans in our sample period is 20 per cent, and it is smaller than average for parent banks (17 per cent) and larger for affiliates (25 per cent). Similarly, the average rate of growth of demand deposits is 20 per cent ( 22 per cent for affiliates and 14 per cent for parent banks). Affiliates are also more profitable and are more leveraged than both parents and standalones. Finally, foreign affiliates within EMU and EU15 are larger than average, less leveraged and less profitable.

Table 3: Correlations between the rate of growth of customer loans and of demand deposits Loan and deposit growth - correlations

Data are from Bankscope. All correlations are statistically significant at the 99 per cent level

\begin{tabular}{lc}
\hline \multicolumn{1}{c}{ Sample } & Correlations \\
\hline All banks & 0.53 \\
Standalones & 0.54 \\
Affiliates & 0.40 \\
Domestic affiliates & 0.50 \\
Foreign affiliates & 0.39 \\
Foreign affiliates (EMU) & 0.19 \\
Foreign affiliates (EU15) & 0.20 \\
Parent companies & 0.81 \\
Domestic parent companies & 0.91 \\
Multinational parent companies & 0.78 \\
\hline
\end{tabular}

As a preliminary step, we have calculated the total correlations between the rate of growth of customer loans and of deposits, distinguishing between standalone banks, domestic and multinational parent banks and domestic and foreign affiliates. Table 3 shows that the average correlation between the loan and deposit growth is 0.53 , and it is statistically significant at the 1 per cent level. Consistent with our Claim 1 (the support effect makes an affiliate's lending capacity less responsive to local shocks on capital and deposits, i.e. on the availability of local funds) and Claim 2 (the substitution effect weakens the link between funds availability and lending. This is more so

\footnotetext{
${ }^{18}$ The largest number of banks in our sample are from Germany, Italy and France; the largest number of affiliates are from Luxemburg, Poland and Spain.
} 
for banking groups operating in countries with little correlated real shocks and definitely less relevant for domestic banking groups operating in a single country), the correlation is slightly smaller than average for affiliates, and it is even smaller for foreign affiliates. Further, the correlation is even smaller for foreign affiliates located within more integrated areas, such as EMU and EU15, providing convincing evidence to Claim 4 (MBNs operating in an integrated area, both in terms of regulations and in terms of currencies, may make a more intense use of their ICMs). The correlation is instead higher than average for parents, both domestic and multinational, although it is smaller for the latter. A possible explanation is that parents are themselves very large banks composed with several dependent units (e.g. branches) and since they normally organize the ICM of the group, they smooth out the balance between loans and deposit of their affiliates, but keep on average stable their own relation between loans and deposits.

The indications of the simple correlations are that banks that may use ICMs can afford a more independent management of their assets and liabilities, thus smoothing the effects of potential idiosyncratic shocks. Furthermore, this is even more the case for those banks operating an internal capital market internationally. To strengthen this preliminary evidence, in the following we will present the results of a more robust econometric analysis, capable of providing further support of our previous claims.

Our econometric framework exploits thoroughly the information contained in the correlations between each bank's growth of deposits and customer loans, using a two step procedure. First, we estimate the time series correlation between each bank's rates of growth of deposits and of customer loans. Due to the frictions in our data set, we lose information for over 4,000 banks, obtaining a sample of 5,527 bank specific correlations. ${ }^{19}$ Second, we use the bank specific correlations as a dependent variable in a standard regression model, where the explanatory variables are: a set of dummy for foreign affiliates, in some specifications distinguishing those located within EMU and EU15; a set of bank specific characteristics; and country dummies. ${ }^{20}$ In practice, our most general specification is the following:

$$
\begin{aligned}
\Delta \text { Correl }_{i j} & =\mathrm{a}_{1}+\mathrm{a}_{2} \text { DUM_DomS } \\
i j & +\mathrm{a}_{3} \text { DUM_For } S_{i j}+\mathrm{a}_{4} \text { DUM_ForS_EMU } U_{i j}+ \\
& +\mathrm{a}_{5} \text { DUM_For_EU15nEMU } U_{i j}+\mathrm{a}_{6} \text { Char }_{i j}+\mathrm{a}_{7} \text { Country }_{j}+\varepsilon_{i j}
\end{aligned}
$$

\footnotetext{
${ }^{19}$ We have also calculated the averages of the time series correlations for different categories of banks. While the average values are higher than those reported in Table 3, foreign affiliates, and in particular those located in EMU and EU15 countries, show as before lower correlations than average.

${ }^{20}$ We have chosen to focus on affiliates because, in a number of unreported regressions we have verified that the behavior of holding companies is not too dissimilar from that of average standalones, giving insignificant coefficients of the associated dummies.
} 
where: $\Delta$ Correl $_{i j}$ is the correlation between the rate of growth (calculated as the annual change of the natural logarithm) of customer loans and of customer deposits of bank $i$ in country $j$ between 2000 and 2008; DUM_Dom $S_{i j}$ is a dummy variable for domestic affiliates; DUM_For $S_{i j}$ is a dummy variable for foreign affiliates; DUM_ForS_EMU $U_{i j}, \quad D U M \_F o r \_E U 15_{i j}, \quad$ and DUM_For_EU15NEMU $U_{i j}$ are dummies for foreign affiliates operating in EMU, in EU15 and in EU15 countries that are not EMU members, respectively; ${ }^{21}$ Char $_{i j}$ are average characteristics of bank $i$ of country $j$ between 2000 and 2000; Country is a set of country dummies; and $\varepsilon_{i j}$ is a standard error term. The model is estimated using weighted least squares, to account for the different time span over which bank specific correlations have been calculated. As bank characteristics we have considered a measure of specialization (the share of customer loans over total assets), since banks active in traditional activities are more likely to have a strong matching between retail funding and lending; a measure of interbank liquidity (the share of bank deposits over total assets), because easier access to the interbank market reduces the need for a strict matching of customer deposits and loans; leverage (the equity to total assets ratio), because more leveraged banks are typically those with better access to funding in capital markets; and size (the logarithm of total assets).

The tests of our earlier claims are based on the signs and significance of the coefficients $a_{2}$ to $\mathrm{a}_{5}$, associated with the dummies for the domestic affiliates and for the foreign affiliates in the different groups of countries. In particular, Claims 1-3 are generically consistent with a negative coefficient for the dummies of domestic and of foreign affiliates ( $a_{2}$ and $a_{3}$ ); Claims 5 and 6 imply negative coefficients of the dummies for EMU and non-EMU EU15 affiliates $\left(a_{4}\right.$ and $\left.a_{5}\right)$, consistent with an even lower correlation in the case of foreign affiliates, the more so if they operate within more integrated areas.

Table 4 presents the results of different specifications of model (1). ${ }^{22}$ In Panel 1 we have included among our explanatory variables only the dummies for domestic and foreign affiliates, and the country dummies. As expected, both coefficients are negative and statistically significant. Moreover, the coefficient of domestic affiliates is larger in absolute value than that of foreign affiliates, consistent with the hypothesis of a smoother functioning of ICMs within a domestic group, although the difference between the two is statistically insignificant. Indeed, the aggregate result is likely to be the outcome of two opposing forces. In the case of domestic affiliates, ICMs

\footnotetext{
${ }^{21}$ For banks that changed their status during the sample period, the dummy takes the value given by the share of years during which it was a subsidiary, over the total number of years it was included in our sample.

${ }^{22}$ Due to the high kourtosis of the original distributions, we have conducted our estimates on a trimmed sample obtained excluding the values below the $5^{\text {th }}$ percentile and above the $95^{\text {th }}$ percentile of the distribution of the dependent variable.
} 
operate more smoothly, but they are used only when support is needed, since substitution is much less relevant within banks operating in the same country.

Table 4: Correlation between loan and deposit growth - baseline specification

The dependent variable is the correlation between the annual percentage change of loans to customers and demand deposits at the bank level. Estimates are made using weighted least squares, using the number of years used to calculate the correlations as weights. The source of data is Bankscope for balance sheet information. All regressions include country dummies. Standard errors are reported in parenthesis. The symbol *** indicates a significance level of 1 per cent or less; ** between 1 and 5 per cent; * between 5 and 10 per cent.

(1)

\section{$-0.092^{* *}$}

(0.032)

$-0.063^{* *}$

(0.023)

Foreign affiliate (dummy)

EMU foreign affiliate (dummy)

EU15 foreign affiliate (dummy)

EU15 non-EMU foreign

affiliate (dummy)

EU15 non-EMU non-UK

foreign affiliate (dummy)

UK foreign affiliate (dummy)

Loans / total assets

Interbank deposits

Leverage

Total assets $(\log )$

Observations

$R^{2}$
(2)

(3)

(4)

(5)

(6)

$\begin{array}{cc}-0.087^{* *} & -0.085^{* *} \\ (0.032) & (0.032) \\ 0.011 & 0.088^{* *} \\ (0.029) & (0.034) \\ -0.186^{* * *} & \\ (0.045) & \\ & -0.277^{* * *} \\ & (0.046)\end{array}$

$(4)$

$\begin{array}{ccc}-0.085^{* *} & -0.086^{* *} & -0.036 \\ (0.032) & (0.032) & (0.030) \\ & & \\ 0.093^{* *} & 0.087^{* *} & 0.121^{* * *} \\ (0.034) & (0.034) & (0.032) \\ & & \\ -0.279^{* * *} & -0.271^{* * *} & -0.200^{* * *} \\ (0.049) & (0.049) & (0.045)\end{array}$

\begin{tabular}{|c|c|c|c|c|c|}
\hline & $\begin{array}{c}-0.186^{* * *} \\
(0.045)\end{array}$ & & $\begin{array}{c}-0.279^{* * *} \\
(0.049)\end{array}$ & $\begin{array}{c}-0.271^{\text {**** }} \\
(0.049)\end{array}$ & $\begin{array}{c}-0.200^{* * *} \\
(0.045)\end{array}$ \\
\hline & & $\begin{array}{c}-0.277^{* * *} \\
(0.046)\end{array}$ & & & \\
\hline & & & $\begin{array}{c}-0.292^{* * *} \\
(0.064)\end{array}$ & & \\
\hline & & & & $\begin{array}{c}-0.318^{* *} \\
(0.101)\end{array}$ & $\begin{array}{c}-0.310^{* * *} \\
(0.094)\end{array}$ \\
\hline & & & & $\begin{array}{c}-0.252^{\text {**** }} \\
(0.073)\end{array}$ & $\begin{array}{l}-0.157^{*} \\
(0.067)\end{array}$ \\
\hline & & & & & $\begin{array}{c}0.260^{* * * *} \\
(0.014)\end{array}$ \\
\hline & & & & & $\begin{array}{c}-0.360^{* * *} \\
(0.017)\end{array}$ \\
\hline & & & & & $\begin{array}{c}-0.005^{* * *} \\
(0.000)\end{array}$ \\
\hline & & & & & $\begin{array}{l}0.004^{*} \\
(0.002)\end{array}$ \\
\hline 5,527 & 5,527 & 5,527 & 5,527 & 5,527 & 5,406 \\
\hline 0.150 & 0.152 & 0.155 & 0.155 & 0.155 & 0.280 \\
\hline
\end{tabular}

In the case of foreign affiliates, both the support and the substitution effects are at work, although with different intensity. Remember that both effects when at work should reduce the correlation between deposits and loans. But the intensity of the two effects is likely to vary, depending on the degree of market integration. Among highly integrated economies, on the one 
hand funds can be transferred more smoothly, but on the other hand business cycles are more correlated, thus making both the support and the substitution functions less relevant. Depending on the relative strength of these two forces, it might be the case that MNBs operating in integrated areas are those that most benefit from the functioning of ICMs, smoothening the tight link between funding and lending capacity. Panels 2 to 4 test precisely this hypothesis.

In Panel 2 we have included an additional dummy for MNBs operating within EMU. Consistent with Claim 5, we find strong evidence that foreign affiliates of EMU holding companies operating in another EMU country have an economic and statistically significant lower correlation between the rates of growth of deposits and of customer loans, with a coefficient of -0.186 . Controlling for this effect, the coefficient of foreign affiliates becomes instead positive (0.011), although statistically insignificant. For EMU foreign subsidiaries, the cumulative effect obtained summing the two coefficients of the dummy for foreign subsidiaries and of the interaction term is economically and statistically significant.

This first evidence is further strengthened by the results reported in Panel 3, showing that also MNBs operating within the larger group of EU15 countries (that includes EMU members) benefit significantly from the functioning of ICMs. The coefficient for the dummy of EU15 foreign affiliates is in this case -0.277 , and it is statistically significant at the 5\% level. Interestingly, the coefficient of foreign affiliates becomes positive (0.088) and statistically significant, suggesting that for the affiliates operating in countries outside EU15, the correlation between the rates of growth of deposits and of customer loans is even stronger than that of standalones. ${ }^{23}$ In this case, therefore, ICMs do work less smoothly, dampening the impact of potential support and substitution effects. This is not entirely surprising, since non-EU15 countries in our sample include mostly those recently admitted to the EU, that have typically higher cultural, linguistic and institutional barriers, as well as less developed financial markets.

In Panel 4 we have distinguished between affiliates within EMU and affiliates within other EU15 countries, but outside EMU, with the aim of verifying the role of the monetary union in facilitating the functioning of internal capital markets for MNBs. On one hand, sharing a common monetary policy and a common currency should facilitate intra-group fund transfers; on the other hand, it is possible that the support and substitution effects are in this case less relevant, due to the higher synchronization of the business cycles within EMU. The evidence of Panel 4 suggests that two effects compensate each other, and the coefficients of the dummies for foreign affiliates in EMU and in the other EU15 countries are both economically and statistically significant, and very

\footnotetext{
${ }^{23}$ Also in this case, for EU15 foreign subsidiaries, the cumulative effect obtained summing the two coefficients of the dummy for foreign subsidiaries and of the interaction term is economically and statistically significant.
} 
similar in size (-0.279 and -0.292 , respectively). Again, the cumulative effects obtained summing the two coefficients of the dummy for foreign subsidiaries and of the interaction terms are economically and statistically significant.

In Panel 5 we have further distinguished between foreign affiliates operating in UK and those operating in the other EU15 countries that are not members of EMU. UK has a key role as a major financial center, and its financial institutions have a large share of transactions denominated in the common European currency. Fund transfers with foreign affiliates operating in UK might therefore be much smoother than with other non-EMU European countries, and therefore be the drivers of the coefficient of the dummy for the non-EMU-EU15 countries in the previous specification. However, the results provide no evidence in favor of this: the coefficient of the dummy for UK affiliates is smaller than that for EMU (-0.252) and the other non-EMU-EU15 affiliates, although the differences are not statistically significant. ${ }^{24}$

Finally, in Panel 6 we have added to our previous specification some bank specific controls. Our previous findings on the smoothness of the functioning of ICMs for foreign affiliates operating in different economic areas are substantially confirmed. As expected, we also find that the correlation between the rate of growth of deposits and of customer loans is on average higher for banks specialized in traditional lending activities, less leveraged, and less active in interbank markets. Bank size has a positive but negligible effect.

The evidence presented in Table 4 provides strong support to our claims on the functioning of ICMs for MNBs operating within well integrated areas. In Table 5 we have further analyzed the role of integration, including among the explanatory variables some measures of economic and institutional proximity, to test our earlier Claim 5, that units that are located in distant countries with different languages or different cultural environment may find more difficulties in actively taking part into a cross-border ICM of an MNB.

In Panels 1 and 2 we have included a dummy for foreign affiliates operating in countries sharing a border with that of the holding company, or where the same language is spoken. In both cases the estimated coefficient is positive, suggesting that stronger proximity has mainly the effect of reducing the impact of the substitution effect, but they are not statistically significant.

\footnotetext{
${ }^{24}$ In unreported regressions we have also analyzed separately the role of Luxemburg, another important banking center, finding that it also has no significant impact on our results.
} 


\section{Table 5: Correlation between loan and deposit growth - The role of proximity}

The dependent variable is the correlation between the annual percentage change of loans to customers and demand deposits at the bank level. Estimates are obtained from weighted least squares, using the number of years used to calculate the correlations as weights. The source of data is Bankscope for balance sheet information, IFS for GDP growth. All regressions include country dummies. Standard errors are reported in parenthesis. The symbol *** indicates a significance level of 1 per cent or less; ** between 1 and 5 per cent; * between 5 and 10 per cent.

\begin{tabular}{|c|c|c|c|c|}
\hline & (1) & (2) & (3) & (4) \\
\hline Domestic affiliate (dummy) & $\begin{array}{l}-0.036 \\
(0.030)\end{array}$ & $\begin{array}{l}-0.038 \\
(0.030)\end{array}$ & $\begin{array}{l}-0.028 \\
(0.030)\end{array}$ & $\begin{array}{l}-0.025 \\
(0.030)\end{array}$ \\
\hline Foreign affiliate (dummy) & $\begin{array}{l}0.118^{* * *} \\
(0.034)\end{array}$ & $\begin{array}{l}0.120^{* * *} \\
(0.032)\end{array}$ & $\begin{array}{l}0.135^{* * * *} \\
(0.032)\end{array}$ & $\begin{array}{l}0.148^{* * *} \\
(0.033)\end{array}$ \\
\hline EMU foreign affiliate (dummy) & $\begin{array}{l}-0.203^{* * *} \\
(0.047)\end{array}$ & $\begin{array}{l}-0.210^{* * *} \\
(0.046)\end{array}$ & $\begin{array}{l}-0.191^{* * *} \\
(0.045)\end{array}$ & $\begin{array}{l}-0.207^{* * *} \\
(0.045)\end{array}$ \\
\hline $\begin{array}{l}\text { EU15 non-EMU non-UK } \\
\text { affiliate (dummy) }\end{array}$ & $\begin{array}{l}-0.306^{* *} \\
(0.095)\end{array}$ & $\begin{array}{l}-0.312^{* * *} \\
(0.094)\end{array}$ & $\begin{array}{c}-0.315^{* * *} \\
(0.094)\end{array}$ & $\begin{array}{c}-0.333^{* * *} \\
(0.094)\end{array}$ \\
\hline UK foreign affiliate (dummy) & $\begin{array}{l}-0.157^{*} \\
(0.067)\end{array}$ & $\begin{array}{l}-0.204^{* *} \\
(0.074)\end{array}$ & $\begin{array}{l}-0.155^{*} \\
(0.067)\end{array}$ & $\begin{array}{l}-0.165^{*} \\
(0.067)\end{array}$ \\
\hline Loans / total assets & $\begin{array}{l}0.259^{* * *} \\
(0.014)\end{array}$ & $\begin{array}{l}0.258^{* * *} \\
(0.014)\end{array}$ & $\begin{array}{l}0.259^{* * *} \\
(0.014)\end{array}$ & $\begin{array}{l}0.260^{* * *} \\
(0.014)\end{array}$ \\
\hline Interbank deposits & $\begin{array}{l}-0.360^{* * *} \\
(0.017)\end{array}$ & $\begin{array}{l}-0.359^{* * *} \\
(0.017)\end{array}$ & $\begin{array}{l}-0.360^{* * *} \\
(0.017)\end{array}$ & $\begin{array}{c}-0.360^{* * *} \\
(0.017)\end{array}$ \\
\hline Leverage & $\begin{array}{l}-0.005^{* * *} \\
(0.000)\end{array}$ & $\begin{array}{l}-0.005^{* * *} \\
(0.000)\end{array}$ & $\begin{array}{l}-0.005^{* * *} \\
(0.000)\end{array}$ & $\begin{array}{l}-0.005^{* * *} \\
(0.000)\end{array}$ \\
\hline Total assets $(\log )$ & $\begin{array}{l}0.004^{*} \\
(0.002)\end{array}$ & $\begin{array}{l}0.004^{*} \\
(0.002)\end{array}$ & $\begin{array}{l}0.004^{*} \\
(0.002)\end{array}$ & $\begin{array}{l}0.004^{*} \\
(0.002)\end{array}$ \\
\hline Common border (dummy) & $\begin{array}{c}0.011 \\
(0.039)\end{array}$ & & & \\
\hline Common language (dummy) & & $\begin{array}{c}0.113 \\
(0.078)\end{array}$ & & \\
\hline Low distance countries (dummy) & & & $\begin{array}{l}-0.098^{*} \\
(0.044)\end{array}$ & \\
\hline Low GDP correlation (dummy) & & & & $\begin{array}{c}-0.123^{* *} \\
(0.045)\end{array}$ \\
\hline $\begin{array}{l}\text { Observations } \\
R^{2}\end{array}$ & $\begin{array}{l}5,406 \\
0.280\end{array}$ & $\begin{array}{l}5,406 \\
0.281\end{array}$ & $\begin{array}{l}5,406 \\
0.281\end{array}$ & $\begin{array}{l}5,406 \\
0.281\end{array}$ \\
\hline
\end{tabular}

In Panel 3 we have disentangled the effects of foreign affiliates operating in the countries that have a distance from that of the holding company that is below the median of the sample distribution. Closer countries are typically more integrated and have more synchronous business cycles, therefore reducing the scope for the substitution effect, but they are also more likely to 
permit a smoother working of ICMs, for example facilitating personal contacts. ${ }^{25}$ It turns out that the second effect prevails, since foreign affiliates operating in geographically closer countries have an economically and statistically lower correlation between the rates of growth of deposits and of customer loans.

Finally, to test the second part of our earlier Claim 2, that the substitution effect weakens the link between funds availability and lending especially for banking groups operating in countries with less correlated real shocks, in Panel 4 we have analyzed the effect of the synchronization of the business cycles, disentangling the average effect of ICMs for affiliates operating in countries that have a bilateral correlation of the rate of growth of GDP with the country of the holding company that is below the sample median. Consistent with our expectation, the larger scope for the substitution effect in the case of less synchronized countries increases the role of ICMs, determining a significant reduction in the correlation between the rates of growth of deposits and of customer loans. Note however, that even when we include this control, the EMU and EU dummies, capturing the degree of integration of financial markets, keep their negative and significant sign.

\section{MNBs and the systemic crisis}

In the previous section we have analysed how ICMs are expected to function under idiosyncratic financial distress and we have shown empirically that they have indeed been functioning so as to isolate lending activities of foreign affiliates from the local availability of funding. This finding is in line with the claim that ICMs may be used to support and stabilise financial markets, but it is not a direct test of how they have functioned in times of distress. Of particular concern is how they behaved during the current crisis, given its pervasiveness and that it impacted all players in the financial sector in Europe and all over the world.

In this section we turn precisely to the assessment of the effects of the recent crisis. We first discuss how the claims outlined in section 3 hold in the case of a systemic crisis and then analyse empirically how the lending policies of foreign affiliates have been faring during the crisis. We will do so, first by using aggregate BIS world data and then our sample of European banks. Clearly, in this setting it is not our intention to provide an interpretation of the causes and consequences of the crisis itself, that have been and are being extensively analyzed elsewhere (see, e.g., Acharya et al., 2009).

\footnotetext{
${ }^{25}$ Although the development of the information technologies has made virtual meetings more common, anybody travelling for example at Frankfurt airport cannot fail to notice that de visu meetings are still very common, in this case within members of the European System of Central Banks.
} 
Previous studies have shown that the presence of MNBs tend to increase stability in host developing countries during times of financial distress since domestic lending dropped during crises much more for domestic banks than for affiliates of MNBs (see for example Clarke et al. 2003, Detragiache et al. 2006). Referring to the US, Morgan et al. (2004) and Kroszner and Strahan (2006) have shown that when in a State there is a significant activity of a banking group that operates across-states, then important macro variables in the State (e.g. growth and employment) tend to be less volatile, the size of the business cycle tends to be reduced and at the micro level loan availability becomes less related to the local banks' capital.

But all what these works do is showing that banking groups seem to have a stabilizing role during idiosyncratic shocks. Our aim in this Section is instead to verify the behavior of MNBs in the current systemic crisis, in which the shocks are highly correlated among the countries in which the MNBs are active. To our knowledge this is the first analysis of the behavior of banking groups, domestic and cross-border, in the turmoil of a systemic crisis.

A well shared perception during the crisis was that MNBs were heavily contributing to a credit crunch. The argument was that, by operating across borders, MNBs had quickly spread a dramatic drop in lending in all countries where they were active, notwithstanding (substantially) stable deposits.

However, a deeper investigation of the functioning of ICMs reveals that this is a simplistic view. Two contradictory claims can emerge here. First, if the shock is systemic then one may expect that being an MNB may not help that much since the ICM cannot activate the support and substitution effect (Claim 6). Second, if ICMs are well organized and functioning, they may attract more external funds relatively to standalone banks (i.e., the "more money" effect described in Box 2). Depositors, for example, may behave differently when the bank belongs to an MNB: the "more money" effect may significantly reduce the negative impact of the shock since the MNB may still be considered a safe harbor. ${ }^{26}$ Hence, if ICMs make the allocation of resources more efficient within MNBs, they may help relaxing the nexus between local lending and funds also during a systemic crisis. MNBs would then have a stabilizing effect (Claim 7).

\subsection{Aggregate evidence on the effects of the crisis on the activities of MNBs.}

A first test of claims 6 and 7 can be performed by extending the analysis of section 2 and looking at the aggregate trends in the activities of MNBs. Specifically, we focus on how local claims of these banks have behaved during the recent financial crisis, from the last term of 2007 to the third term of 2009. The key question is whether during the crisis MNBs have been unwinding

\footnotetext{
${ }^{26}$ Indeed, de Haas and van Lelyveld (2010) illustrate this effect showing that in crisis affecting a national banking systems, foreign subsidiaries increase their deposits, contrary to domestic banks.
} 
their assets held through their foreign affiliates in host countries, or, in contrast, whether they have been channelling liquidity to their subsidiaries to support them.

We argued in Section 2 that local claims had been more stable than total foreign claims in 2008 and 2009. If we consider the EU27, the total value of local claims denominated in local currency, once converted in US Dollars (as reported above in Figure 2 of section 2) amounted roughly to $\$ 4.400$ billion at the end of 2007 , it declined by about 400 billion by the end of 2008 , but was already back almost at the 2007 level by the end of the third term of 2009 ( $\$ 4,416$ billion). This pattern is consistent in all subgroups of EU countries, including the UK. In the NMS the absolute value of local assets by mid 2009 is even larger than at the end of 2007. This trend is also similar in the non-EU advanced economies like the US.

The stability of local claims stands out even more clearly if we adjust for exchange rate fluctuations, by constructing index numbers measured in national currencies for the EMU12 aggregate and for some individual countries (Figure 5A). Besides for the US, in all other country groups the value of local claims measured in local currency was higher at the end of the third term of 2009 than at the beginning of 2007. This is also true for Hungary and Poland, countries where foreign banks are the major players in the financial crisis and which have been through a particularly severe recession in 2008 and 2009.

Figure $5 \mathrm{~A}$

Total Local Claims in Local Currency expressed in national currencies EMU12 and specific countries

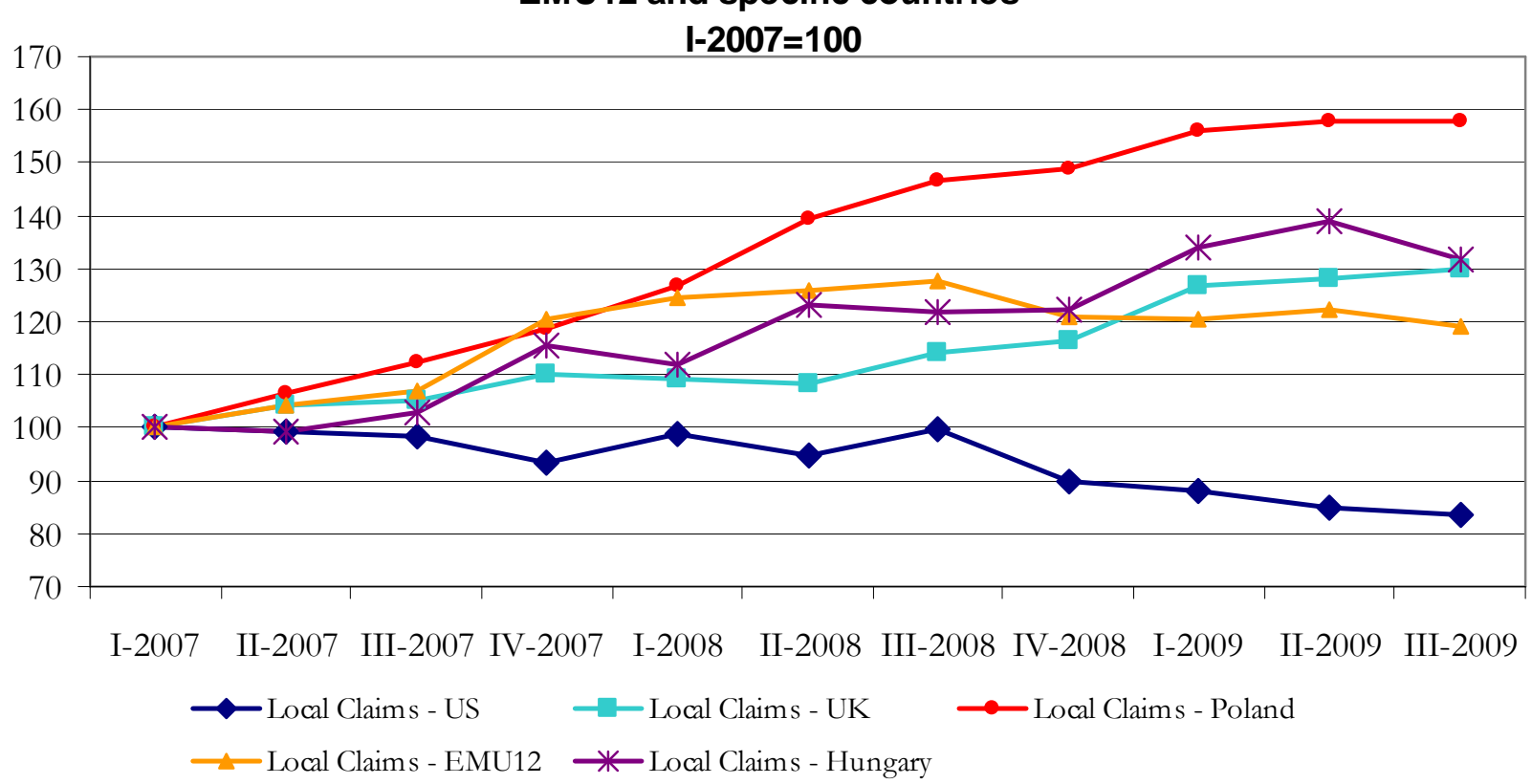

In Figure 5B we also report local claims denominated in foreign currency. These figures should be taken as proxies for likely trends, because, as mentioned above, they are estimated and their 
allocation to individual countries is likely to be biased. Moreover, since the currency basket of these claims is not reported, we keep them in current US \$ (as BIS does). Besides for the UK, also these claims are higher at the end of 2009 than at the beginning of 2007 in the EMU 12 countries, Hungary and Poland.

Figure 5 B

Total Local Claims in Foreign Currency

EMU12 and specific countries

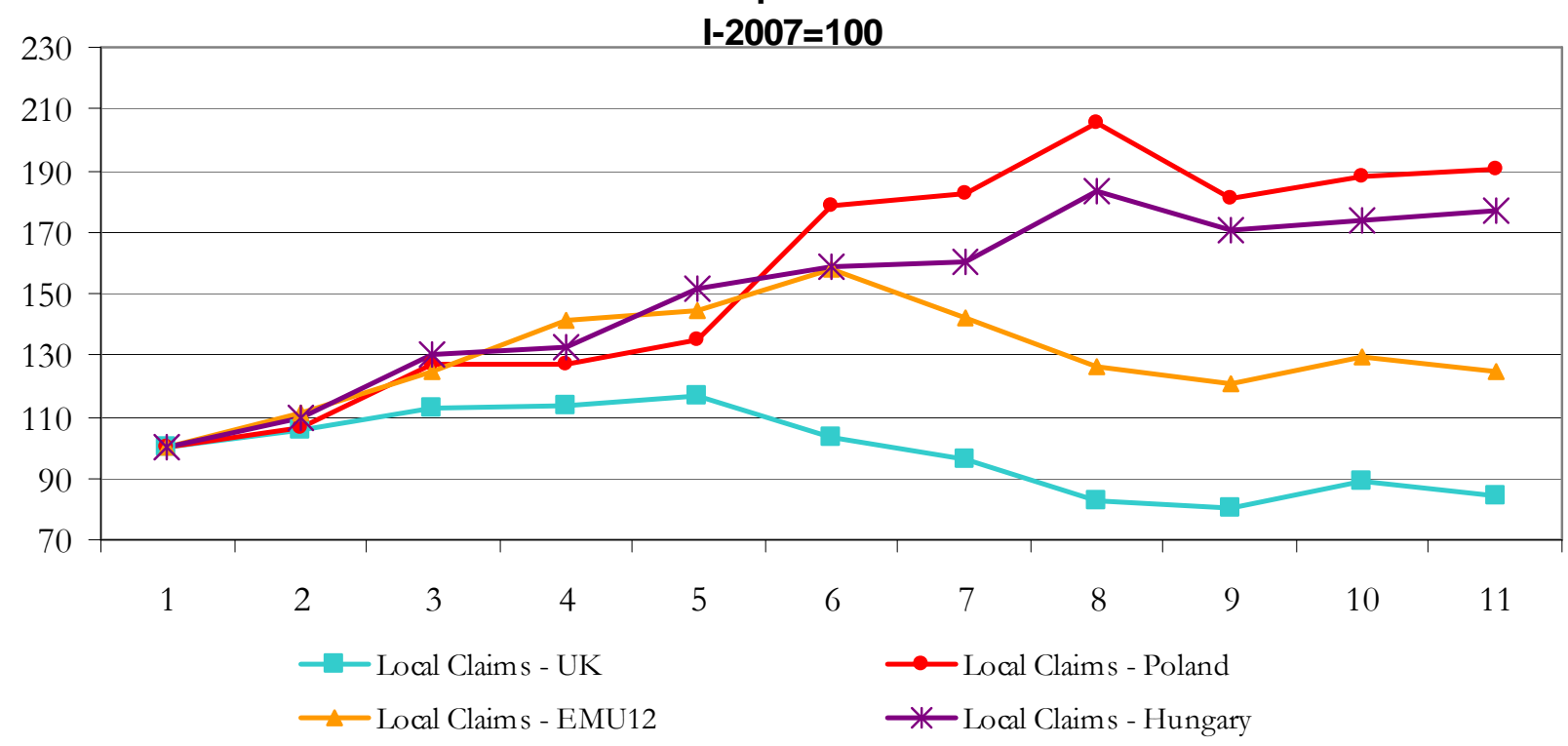

Source: BIS Statistics; same scale in the horizontal axis as in Figure 5A.

To better understand investment policies of foreign banks during the crisis and particularly whether these bank have been instrumental in channelling financial resources towards host countries rather than the opposite, it is useful to relate trends in assets to trends in liabilities in local currency towards local residents (see Box 1 for the definitions). The issue here is understanding, first how far claims in local currency are strictly funded by local deposits and other liabilities and, second, whether during the crisis resources acquired in a given country have been transferred to affiliates based in other countries or to headquarters. Figure 6 reports the ratio between these assets and liabilities for the EMU 12 and the other countries reported in Figure 5 from the first term of 2007 to the third of 2009. The evidence is particularly interesting and in line with hypothesis that foreign banks have been supporting local assets through cross border funding.

Indeed it stands out that this ratio is always larger than one (besides for the UK at the beginning of the period). In Hungary it is the highest, at 1.8. Also, this ratio is stable and even increasing for most countries. Now local assets not funded by local liabilities in local currency can either be funded by local liabilities in foreign currency (which are not reported in the BIS' statistics but they are likely to be pretty small) or by cross border funds, channelled either through the global 
market or through the ICM. In other words, during the crisis an increasing share of the local assets of foreign subsidiaries have been funded by cross border financial flows.

Figure 6: Ratio Total Claims over Total Liabilities in local currency

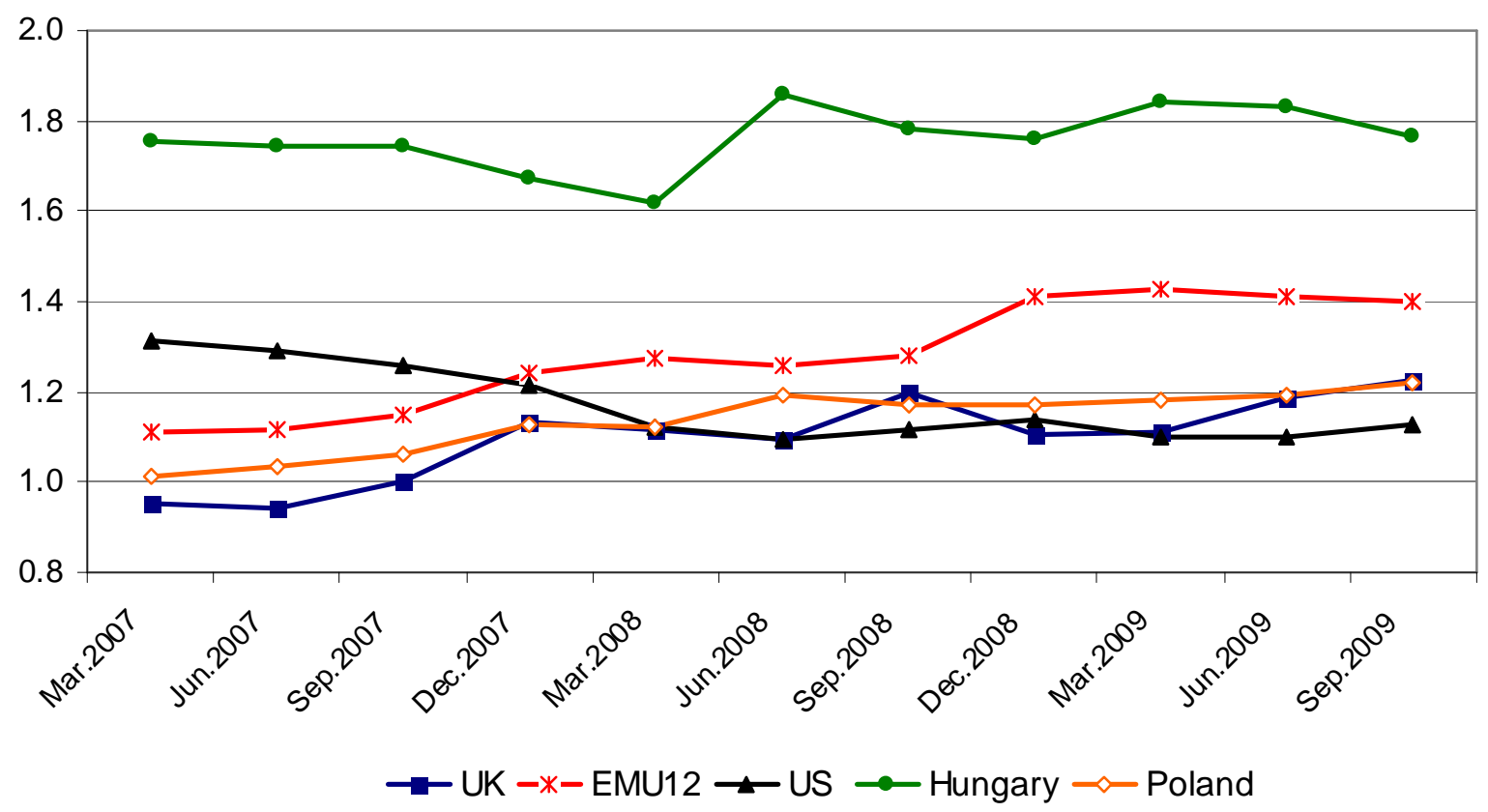

This preliminary descriptive evidence that lending and investment policies of multinational banks have been stable, if not rising, during the period of the crisis is now tested econometrically. Using the same quarterly data described above for the period between 1999 and 2009 and for a sample of 49 developed and developing countries, we look at whether the time trends of local claims denominated in domestic currencies of foreign affiliates is affected by the crisis, taking them as a ratio of local liabilities denominated in domestic currencies, or of total financial assets in the country, obtained from BIS data.

The results are reported in Table 6 . Since both ratios show a high cross-country dispersion, we used a quantile regression technique evaluated at the median, also including country fixed effects. Panel 1 shows that on average the ratio of local claims to local liabilities has increased since 1999, as shown by the positive and significant coefficient of a linear time trend. Moreover, the growth has accelerated in the post-crisis period, as shown by the positive and statistically significant coefficient of the post crisis dummy, that takes the value of one from the fourth quarter of 2007 (Panel 2). In Panel 3 we have further specialized our analysis, interacting the post-crisis dummy with a set of dummies for different grouping of countries, to see if the effect of the crisis has been heterogeneous across regions. The results show that the ratio of local claims to local liabilities has increased in all 
geographic areas, with the only exception of other non-European developed countries. The effect has been stronger in the NMS countries and in the main developing countries, smaller and non significant in the EU countries that are not EMU members neither part of NMS.

\section{Table 6: Claims-liabilities ratio. The effect of the crisis}

In Panels 1-3, the dependent variable is the ratio between total claims and total liabilities denominated in local currencies, of foreign affiliates; in Panel 4-7 is the ratio between total claims by foreign affiliates and total credit to the private sector in the country. The source of data is BIS for claims and liabilities, IMF for private credit. All estimates are conducted using quantile regression technique, evaluated at the median, and include country dummies. MNS countries include Bulgaria, Czech Republic, Hungary, Latvia, Lithuania, Poland, Romania; EMU countries include: Austria, Belgium, Finland, France, Germany, Greece, Ireland, Italy, Luxembourg, Netherlands, Portugal, Spain, Slovenia; Main developing countries include China, India, Malaysia, South Korea, South Africa, Singapore, United Arab Emirates; other are all remaining countries in the sample. The symbol *** indicates a significance level of 1 per cent or less; ** between 1 and 5 per cent; * between 5 and 10 per cent.

(1)

Time trend
Post crisis (dummy)
Post crisis * NMS countries
Post crisis * EU-noEMU-no-NMS
countries
Post crisis *Main developing
countries
Post crisis * EMU countries

Post crisis * Other countries

Observations

Pseudo R2
(2) $-0.001^{* *}$ (0.000)

$-0.001^{* * *}$
(0.000) $0.108^{* * *}$ (0.008)

(3)

(4)

(5)

(6)

$\begin{array}{cccc}-0.001^{* * *} & 0.003^{* * *} & 0.002^{* * * *} & 0.002^{* * *} \\ (0.000) & (0.000) & (0.000) & (0.000) \\ & & & \\ & & 0.047^{* * *} & \\ & & (0.005) & \end{array}$

\begin{tabular}{|c|c|c|c|}
\hline $\begin{array}{l}0.342^{* * *} \\
(0.000)\end{array}$ & & & $\begin{array}{l}0.020^{* *} \\
(0.007)\end{array}$ \\
\hline $\begin{array}{c}0.108^{* * *} \\
(0.000)\end{array}$ & & & $\begin{array}{l}-0.004 \\
(0.010)\end{array}$ \\
\hline $\begin{array}{c}0.098^{* * *} \\
(0.000)\end{array}$ & & & $\begin{array}{l}0.033^{* * *} \\
(0.009)\end{array}$ \\
\hline $\begin{array}{c}0.072^{* * *} \\
(0.000)\end{array}$ & & & $\begin{array}{c}0.070^{* * * *} \\
(0.007)\end{array}$ \\
\hline $\begin{array}{c}0.098^{* * *} \\
(0.000)\end{array}$ & & & $\begin{array}{c}6.952^{* * * *} \\
(0.010)\end{array}$ \\
\hline 1,879 & 9,079 & 9,079 & 9,079 \\
\hline 0.16 & 0.55 & 0.55 & 0.56 \\
\hline
\end{tabular}

These results are substantially confirmed by the analysis of the evolution of the local claims of foreign affiliates as a ratio of total financial assets in the country. Also this ratio has been increasing since 1999, as shown by the positive and statistically significant of the coefficient of the time trend, in Panel 4. However, the crisis has not significantly altered its evolution, as shown by the insignificant coefficient of the post-crisis dummy in Panel 5. Finally, analyzing separately the 
effect of the crisis across different groups of countries shows that this ratio has significantly raised within EMU affiliates.

\subsection{Micro effects of the crisis}

Since our bank specific micro-data cover the period from 2000 to 2008, we have also investigated the effects of the financial crisis on the relationship between deposits and customer loans. Unfortunately, the empirical model of equation (1) is unsuitable to analyze the effects of the crisis, because it is impossible to calculate the correlation between the rates of growth of deposits and loans at the bank level, with only two years observations since the summer of 2007. For this reason, we have chosen a specification similar to the one adopted for the analysis at the aggregate level, verifying if the bank specific ratio of customer loans to deposits has changed significantly during the crisis, and in particular if these changes have been different for foreign affiliates operating in different areas (which we couldn't test with aggregate data). In practice, we have estimated the following specification of a difference in difference model around the event of the crisis:

$$
\begin{aligned}
\text { ratio }_{i j t} & =\mathrm{a}_{1}+\mathrm{a}_{2} \text { DUM_Crisis } * \text { DUM_ForS_EMU } U_{i j}+\mathrm{a}_{3} \text { DUM_Crisis } * \text { DUM_For_EU15nEMU } U_{i j}+ \\
& +\mathrm{a}_{4} \text { DUM_Crisis } * D U M_{-} \text {For_nEU15 }{ }_{i j}+\mathrm{a}_{5} \text { DUM_ForS_EMU } U_{i j} \\
& +\mathrm{a}_{6} \text { DUM_For_EU15nEMU } U_{i j}+\mathrm{a}_{7} \text { DUM_For_nEU15 } 5_{i j}+ \\
& +\mathrm{a}_{5} \text { Char }_{i j t-1}+\mathrm{a}_{6} \text { Year }_{t}+\mathrm{a}_{7} \text { Country }_{j}+\varepsilon_{i j t}
\end{aligned}
$$

where: ratio $_{i j t}$ is the ratio between customer loans and customer deposits of bank $i$ in country $j$ at time $t$; DUM_Crisis is a dummy taking the value of one in 2007 and 2008; DUM_ForS_EMU $U_{i j}$, $D U M \_F o r \_E U 15 n E M U_{i j}$ and DUM_For_nEU15 $5_{i j}$ are dummy variables that take the value of one if bank $i$ of country $j$ at time $t$ is a foreign subsidiary of a holding company located, respectively, in EMU, in EU15 countries that are not EMU members, and in the remaining EU27 countries; Char $_{i j t-1}$ are characteristics of bank $i$ of country $j$ at time $t-l$ (the logarithm of total assets and leverage); Year $_{t}$ is an yearly time dummy; Country $y_{j}$ is a country dummy; and $\varepsilon_{i j t}$ is a standard error term. Due to the high kurtosis of the dependent variable, we have run the estimates excluding observations below the $5^{\text {th }}$ and above the $95^{\text {th }}$ percentile of the sample distribution.

The test of the effect of the financial crisis on the functioning of ICMs for cross-border groups is based on the sign and significance of coefficients $a_{2}$ to $a_{4}$. A positive and significant value would imply that foreign banks with access to ICMs reduced their loans-deposits ratio less than the control 
group of banks, and therefore had a stabilizing effect after the shock induced by the financial crisis. Clearly, a negative coefficient would imply the opposite.

Table 7 presents the results of the estimation of equation (2), distinguishing the impact of the crisis on foreign affiliates located in EMU, in non-EMU-EU15 countries and in non-EU15 countries. Panel 1 presents the estimates obtained using an OLS specification, including unreported country and year dummies. The coefficients of the interaction terms between the crisis and foreign affiliates located in the three areas considered are all positive, although only the one for non-EU15 countries is statistically significant, at the 10 per cent level.

\section{Table 7: Loan-deposit ratio at the bank level. The effect of the crisis}

The dependent variable is ratio between customer loans and deposits. The source of data is Bankscope. All regressions include time dummies; the regression in Panel 3 includes bank specific fixed effects. Panel 1 reports estimates obtained using OLS; Panel 2 estimates obtained using quantile regression methods, evaluated at the median; Panel 3 is a fixed effect panel. In Panel 1, robust standard errors adjusted for clustering at the bank level are reported in parenthesis; standard errors in Panels 2 and 3 are unadjusted. The symbol *** indicates a significance level of 1 per cent or less; ** between 1 and 5 per cent; * between 5 and 10 per cent.

\begin{tabular}{|c|c|c|c|}
\hline & $\begin{array}{l}\text { OLS } \\
\text { (1) }\end{array}$ & $\begin{array}{c}\text { Median regression } \\
\text { (2) }\end{array}$ & $\begin{array}{c}\text { Fixed effects } \\
\text { (3) }\end{array}$ \\
\hline Post crisis $*$ EMU subsidiaries & $\begin{array}{c}0.029 \\
(0.134)\end{array}$ & $\begin{array}{l}-0.005 \\
(0.043)\end{array}$ & $\begin{array}{l}-0.030 \\
(0.022)\end{array}$ \\
\hline Post crisis * EU15-non-EMU subsidiaries & $\begin{array}{c}0.039 \\
(0.058)\end{array}$ & $\begin{array}{c}0.222 \\
(0.113)\end{array}$ & $\begin{array}{c}0.021 \\
(0.052)\end{array}$ \\
\hline Post crisis * non-EU15 subsidiaries & $\begin{array}{l}0.277^{*} \\
(0.105)\end{array}$ & $\begin{array}{l}0.313^{* * *} \\
(0.036)\end{array}$ & $\begin{array}{l}0.224^{* * *} \\
(0.017)\end{array}$ \\
\hline EMU subsidiaries (dummy) & $\begin{array}{c}0.102 \\
(0.128)\end{array}$ & $\begin{array}{l}0.148^{* * * *} \\
(0.025)\end{array}$ & $\begin{array}{l}0.037^{*} \\
(0.019)\end{array}$ \\
\hline EU15-non-EMU subsidiaries (dummy) & $\begin{array}{c}0.028 \\
(0.039)\end{array}$ & $\begin{array}{l}-0.021 \\
(0.060)\end{array}$ & $\begin{array}{c}0.005 \\
(0.062)\end{array}$ \\
\hline non-EU15 subsidiaries (dummy) & $\begin{array}{c}0.099 \\
(0.076)\end{array}$ & $\begin{array}{l}0.064^{* *} \\
(0.023)\end{array}$ & $\begin{array}{l}0.049^{* * *} \\
(0.015)\end{array}$ \\
\hline Lagged leverage & $\begin{array}{c}0.009 \\
(0.006)\end{array}$ & $\begin{array}{l}0.002^{* * *} \\
(0.000)\end{array}$ & $\begin{array}{l}0.005^{* * *} \\
(0.001)\end{array}$ \\
\hline Lagged total assets (ln.) & $\begin{array}{l}0.077^{* * *} \\
(0.014)\end{array}$ & $\begin{array}{l}0.057^{* * *} \\
(0.001)\end{array}$ & $\begin{array}{l}0.218^{* * *} \\
(0.006)\end{array}$ \\
\hline $\begin{array}{l}\text { Observations } \\
R^{2} \text { (Pseudo } R^{2} \text { in Panel 2) }\end{array}$ & $\begin{array}{r}25,119 \\
0.223 \\
\end{array}$ & $\begin{array}{r}25,119 \\
0.127 \\
\end{array}$ & $\begin{array}{r}25,119 \\
0.103 \\
\end{array}$ \\
\hline
\end{tabular}

Since, despite the trimming, our data might be affected by the presence of outliers, in Panel 2 we report the results obtained using a more robust quantile regression technique, evaluated at the median. The results substantially confirm the previous findings: the coefficients of the dummies for 
foreign affiliates located in EU15 are not statistically significant, while that of the dummy for the new accession countries is positive and statistically significant at the two per cent level. Finally, in Panel 3 we have estimated a model with fixed bank effects, that once again confirms the robustness of the previous finding.

These results can be interpreted at the light of Claims 6 and 7 above. Foreign banks had a stabilizing effect during the crisis in Eastern Europe's NMSs, which is in line with claim 7 that these banks can be effective provider of funds locally even during a systemic distress. This result is also probably driven by the fact that in the NMS, MNBs are by far the dominant players, and domestic banking is extremely weak. However in other areas these banks have essentially been behaving like national banks, showing that they had been equally affected by the pervasiveness of the crisis. This is in line with Claim 6.

In summary, these results based on bank specific data during the crisis show that foreign affiliates certainly had not a destabilizing effect, since their loan-deposit ratio has remained constant, and at higher levels than that of domestic banks. Contrary to a diffused misperception, we find no evidence that these banks have been funnelling resources away from any of their host countries. That the working of ICMs did not allow foreign affiliates to have a significant stabilizing effect within EU15 countries is not entirely surprising, due to the systemic nature of the recent crisis, that has made nearly impossible to smooth the shocks within a group. If all banks are simultaneously hit by a similar event, there is no benefit in transferring funds from one unit to the other. However, we find that ICMs had indeed a stabilizing effect in the case of affiliates located in the NMS, where the impact of the shock was more diverse, because of the lower economic integration.

\section{Concluding remarks: insights for a better regulatory design of MNBs in Europe}

MNBs are subject to regulations by the many national authorities of the countries in which they operate. In this concluding Section we finally provide some insights on if and how a change in the European regulatory environment for MNBs is needed. Our aim is not to contribute with a comprehensive and self contained reform proposal to the current debate that is taking place in Europe, and in the rest of the world. Rather, we want to illustrate what are the implications of our previous discussion and results on the functioning of the ICM in cross-border banks for the delicate issue of regulatory reforms in a globalized banking sector. These important ingredients are often missing in the design of policy measures, although we believe that, on the contrary, they should provide the bedrock on which regulations are built. 
Multinational banks have emerged from the financial crisis being perceived as an important cause for systemic risk and a source of volatility in the international financial market. However, we have shown that these conclusions are driven by a non adequate understanding of what these banks do and how they function, particularly for what concerns retail banking activities. As shown by the econometric results of Section 3.1, affiliates of MNBs use extensively their ICMs, and this has a significant impact on the correlation between the rates of growth of customer loans and deposits. In times of distress, this can either have a positive effect on financial stability, supporting foreign subsidiaries in distress or, on the contrary, can increase instability, funnelling resources away from affiliates and thereby contributing to the spreading of shocks. The evidence of Section 4.2, showing that during the crisis the ratio of local bank claims to liabilities did not decline, and in fact it even increased in some groups of countries, supports however the positive view that MNBs enhance financial stability. This aggregate pattern is further confirmed by the micro-evidence based on the sample of the largest European banks, showing that, compared to self standalone domestic banks and domestic banking groups, subsidiaries of MNBs have been able to isolate their lending activities from fluctuations in funds, and that they have been better able to profit from positive upswings in lending conditions. The evidence also supports the view that this has been done through the ICM.

In Europe multiple national authorities are involved in the supervision of a single MNB, often in an uncoordinated way. The current regulatory framework has several shortcomings. Supervisors tend to operate only in the interest of their own country without due considerations to the cross-border spillover implications of their own decisions. Under several scenarios, this framework is unable to produce the relevant and timely information for prompt supervision and regulation. The shortfalls of the current regulatory and supervisory framework are already evident in ordinary times, but they become even more compelling in times of distress. As highlighted by the recent crisis, cooperation and coordination between national supervisors often proved ineffective, since the crisis has been assessed mainly at the national level, and remedial actions were defined almost exclusively at the country level.

Although the "single banking license scheme" was introduced in Europe with the purpose of facilitating free access within the Single European Market and of ensuring a level playing field, in fact neutrality in the legal structure is not guaranteed, and banks are not free to choose their preferred structure on the basis of pure economic and organizational considerations. ${ }^{27}$

\footnotetext{
${ }^{27}$ The single license applies to branches of an MNB that are subject to the regulation and supervision of the authority regulating the parent company. Subsidiaries instead are considered independent despite their being part of a group and each of them is under the regime of the authority of the country in which they are based. Thus, rules applied to affiliates of the same group often differ and conflict.
} 
We have illustrated that different types of foreign incorporation (e.g. branches and subsidiaries) give rise to different liability structures between the bank's units within the group, and hence different incentives to the functioning of ICMs. An important point that has received little attention in the current debate (both academic and in the regulatory arena) is the lack of neutrality of the regulatory framework, certainly in Europe but also in other countries, with respect to the particular organization of the multinational banks (with independently incorporated subsidiaries rather than with foreign branches). We have seen that ICMs work well and show their "bright side" if (i) liquidity and capital are really free to flow among units, (ii) the information is free to flow within the organization without impediments, (iii) the incentives within the organization and its units are well designed.

The current regulatory framework in Europe shows a bias in favour of structuring MNBs with branches (with the single passport). However, as previously discussed, branches may not be the best organization to address the internal incentive issues of point (iii). In principle, with subsidiaries one could identify clear responsibilities of local managers and units and thus give them the right incentives. ${ }^{28}$ Independent local managers are in a better position to make use of "soft information" that would instead be very difficult if not impossible to transmit for the functioning of a fully centralized ICM. ${ }^{29}$ With an organization based on branches, instead, local managers in foreign countries may be exposed to and feel that the ICM actually expropriates the capital and liquidity that has been produced locally by their branches.

The reform for regulation and supervision should not ignore these organizational issues and at least be neutral with respect to the choice between branches and subsidiaries. It is a managers' task that of choosing the best organization for their bank, and regulation should not impose a preference. Clearly, one could argue that in the current environment branches are to be preferred since, to some extent, they allow a consolidated supervision of the MNB. However, it is also clear that this is simply the suboptimal consequence of the current state of affairs in regulation and supervision of MNBs. Along the same line of reasoning, reform proposals meant at ring fencing subsidiaries in host countries and forcing systemically relevant branches to be transformed into subsidiaries, like those put forward within the FSB Standing Committee on Supervision and Regulatory Cooperation (Turner, 2009), may restrict considerably the optimal functioning of the ICM.

\footnotetext{
${ }^{28}$ It is also worth mentioning that a subsidiary structure may be preferred and rewarded by markets in time of distress since it naturally allow to identify units and cross-liabilities among them.

${ }^{29}$ Currently, national regulations on privacy limit the possibility for units to exchange information on their activities with their partners that are independent entities of the same group. This is another undesirable bias of regulation that affects the internal organization of MNBs.
} 
An additional problem is the geographical extent of the regulatory harmonization within Europe. Our empirical findings of Section 3.1, based on bank level data, clearly illustrate that also in normal times the correlation between the rates of growth of loans and deposits of foreign affiliates is lower than that of domestic banks, especially for those affiliates that belong either to the Euro-area or to the restricted set of countries that are more integrated in Europe (i.e., the EU15 group). To this extent, our evidence shows that ICMs and the external capital markets are by and large complementary. When the external capital markets are less integrated, due to regulatory constraints or because they involve different currencies, then MNBs' affiliates are de facto using the ICMs to a very limited extent, and therefore show no relevant differences with respect to domestic banks. ${ }^{30}$

In this respect, the different degree of integration among European countries poses an issue of timing and geography of the reform agenda. Within the Euro area or the EU15 countries, where ICMs are already in place and working, harmonising rules and creating a playing level field is at the same time urgent (here is where the action is anyway) and not exceedingly difficult (rules are not too divergent). As for the other EU countries, the harmonisation necessary to get ICMs started are probably larger and more difficult to achieve. And although the large and growing presence of MNBs in these countries that we documented in Section 2 would make it preferable to bring them on board of a pan-European regulatory reform, if this risks to be unfeasible, then it is more urgent to involve those countries that are in the restricted groups of more integrated economies in Europe. MNBs located in those countries are those that we may indeed expect to benefit from the well functioning of ICMs in MNBs, and that would suffer the most from restrictive regulations.

We think our analysis shows that it would make a lot of sense for integrated European countries to contemplate a new and specific framework for European MNBs, that would allow these banks to set-up a truly integrated organization with its well functioning ICMs. This framework would define the responsibilities and the powers of the parent company, the branches and independent subsidiaries, providing due protections to minorities and creditors is granted. With this respect, some commentators have referred to this proposal as a $28^{\text {th }}$ regime for MNBs, in addition to those available to banks in the 27 member states belonging to the European Union. It is not clear under what conditions banks should opt for this regime. However, in the end this should be left to

\footnotetext{
${ }^{30}$ Although further scrutiny on the causes of this effect are needed, since the effect related to the Euro seems to be stronger, a possible interpretation is that an ICM that operates across countries with different currencies incurs in the additional cost of exchange rate risk. Indeed anecdotal evidence illustrates that activities of ICMs across countries almost always involve currency swaps. Furthermore, transfers of liquid assets within ICMs are often used in the country of destination as collaterals with the local central bank to obtain liquidity. Since the central banks tend to associate lower volatility to local treasury bills, limited integration (e.g. outside EU15) may involve significant impediments to ICMs.
} 
their choice, considering that this regime would anyhow be consistent with the optimal functioning of ICMs. This regime should contemplate a specific treatment for MNBs in terms of regulation and supervision, along the line of the proposals that have already been discussed in Europe (i.e., enhancing coordination among countries through strengthened colleges of supervisors overseen by a newly created European Banking Authority, and possibly defining rules for the allocation of the costs of rescuing those banks in case of distress). ${ }^{31}$ The actual implementation of this $28^{\text {th }}$ regime will certainly encounter all the difficulties that the current debate in Europe for a redesign of regulation is experiencing. However, all such constraints will be faced by any significant reform of the status quo.

Independent on the specific setup that will be eventually chosen, the key policy message of our analysis is that a sensible revision of the current framework should seriously keep into account its effects on the organizational format that MNBs adopt for their ICMs. And, in addition, that the effectiveness of any regulatory reform strictly depends on the level of integration between the countries where the bank operates.

\footnotetext{
31 To some extent this new regime for truly European players is close to the dual system that is in place in the US according to which banks active at the level of the entire nation are under the federal scrutiny (with a federal charter, associated federal laws and a federal supervisor).
} 


\section{$\underline{\text { References }}$}

Acharya, V.V., Imbs, J., and Sturgess, J., (2006) "Finance and efficiency of capital allocation" 2006.

Acharya, V.V., Richardson, M. (eds.), (2009), Restoring Financial Stability: How to Repair a Failed System, Wiley.

Berger, A. N., et al. (1999). "The Consolidation of the Financial Services Industry: Causes, Consequences, and Implications for the Future,” Journal of Banking and Finance 23, 135-194.

Berger, A.N. (2007) "Obstacles to a global banking system: "Old Europe" versus "New Europe"", Journal of Banking and Finance 31, 1955-1973.

Billett, M., and Mauer D. (2003), "Cross subsidies, external financing constraints, and the contribution of the internal capital market to firm value", Review of Financial Studies 16, 11671201.

Boot A.W.A. and Schmeits A. (2000) "Market discipline and incentive problems in conglomerate firms with applications to banking".

Brusco S., Panunzi F. (2005), "Reallocation of Corporate Resources and Managerial Incentives in Internal Capital Markets," CEPR Discussion Papers 2532.

Calzolari G. and Loranth G. (2005), "Regulation of multinational banks: a theoretical inquiry", European Central Bank working Paper No. 431, forthcoming in Journal of Financial Intermediation.

Cerutti E., Dell'Ariccia G, Martınez Peria M.S. (2007) "How banks go abroad: Branches or subsidiaries?” Journal of Banking \& Finance 31,2007, 1669-1692.

Chan-Lau J.M. et al. (2007), "Identifying contagion risk in the International banking system: an exgtreme value theorem approach?" IMF.

Chevalier, J.A. (2000), "What do we know about cross-subsidization? Evidence from the investment policies of emerging firms", Working Paper (University of Chicago GSB).

Clarke, G., Cull, R., Martinez Peria, M.S., Sánchez, S.M. (2003), "Foreign Bank Entry: Experience, Implications for Developing Economies, and Agenda for Further Research", The World Bank Research Observer 18, 25-59.

de Haas, R., van Lelyveld, I. (2010), "Internal capital markets and lending by multinational bank subsidiaries", Journal of Financial Intermediation 19, 1-25.

Dermine J. (2005), “European Banking Integration: Don't Put the Cart before the Horse" INSEAD, Fontainebleau 17 September 2005.

Derviz, A., et al. "Cross-Border Lending Contagion in Multinational Banks", ECB Working Paper Series, NO 807 / September 2007.

Detragiache E., Gupta P. et al. (2006), "IMF "Foreign banks in poor countries: Theory and Evidence", 7th Jacques Polak Annual Research Conference, November 9-10, 2006. 
Dietrich D, Vollmer U. (2006) "Bank internationalization strategies: the role of bank capital regulation", Halle Institute for Economic Research.

Eisenbeis R.A., Kaufman G.G. (2006), "Cross-Border Banking: Challenges for Deposit Insurance and Financial Stability in the European Union”, Federal Reserve Bank of Atlanta, Working paper 2006/15a.

F.S.A. (2009), "A regulatory response to the global banking crisis: systemically important banks and assessing the cumulative impact", Discussion Paper.

Focarelli D., Pozzolo A.F. (2005), "Where Do Banks Expand Abroad? An Empirical Analysis", Journal of Business, 78, 2435-2463.

Focarelli, D., Pozzolo, A.F. (2001), "The patterns of cross-border bank mergers and shareholdings in the OECD countries", Journal of Banking and Finance 25, 2305-2337.

Frexias X., (2009) "Systemic Risk and Prudential Regulation in the Global Economy" (2008) section in "Globalization And Systemic Risk" World Scientific Studies in International Economics, Evanoff D.D., Hoelscher D.S. (Editor), Kaufman G.G.(Editor).

Gertner R. H. et al. (1994) "Internal versus External Capital Markets," NBER Working Papers 4776, National Bureau of Economic Research.

Gertner, R., et al., (2002), "Learning about internal capital markets from corporate spinoffs", Journal of Finance 57:2479 2506.

Goodhart, C. and Schoenmaker D. (2009) "Fiscal Burden Sharing in Cross-Border Banking Crises" forthcoming in: International Journal of Central Banking 5, 2009.

Gual J. (2004) "The integration of EU Banking Markets", IESE, Barcelona and CEPR Discussion Paper No. 4212, January 2004.

Hart O., Holmström B.R., (2002), "A Theory of Firm Scope”, MIT Department of Economics Working Paper No. 02-42.

Havrylchyk, O. and Jurzyk, E., (2006) "Profitability of foreign banks in Central and Eastern Europe: Does the entry mode matter?," BOFIT Discussion Papers 5/2006, Bank of Finland, Institute for Economies in Transition.

Houston, J., F. James, C (1998) “Do bank internal capital markets promote lending?" Journal Banking of Finance, 22, August 1998.

Houston, J.F., James, C., Marcus, D. (1997) "Capital market frictions and the role of internal capital markets in banking", Journal of Financial Economics 46.

Inderst, R., and Laux C., (2000), "Incentives in internal capital markets: capital constraints, competition, and investment opportunities", Working Paper (University College London).

Kahn C., and Winton A., (2004) "Moral Hazard and Optimal Subsidiary Structure for Financial Institutions," Journal of Finance, American Finance.

Khanna, N., and Tice S. (2001), "The bright side of internal capital markets", Journal of Finance 56:1489 1528. 
Kroszner R.S., (2008) "The effect of removing geographical restrictions on banking in the United States: lessons for Europe" Financial Markets, Institutions \& Instruments, Vol. 17, Issue 1, pp. 518, February 2008.

Kroszner, R.S., and Strahan P.E. (2006). "Regulation and Deregulation of the U.S. Banking Industry: Causes, Consequences, and Implications for the Future," unpublished paper.

Laeven L. and Valencia F(2008), "Systemic Banking Crises, a New Database" IMF Working Paper No. 08/224.

Lamont, O. (1997), "Cash flow and investment: evidence from internal capital markets", Journal of Finance 52:83 109.

Mc Cauley R., Mc Guire P. and von Peter G. (2010), "The architecture of global banking: from international to multinational?" BIS Quarterly Review, March issue.

Meyer, M., Milgrom P., Roberts J., (1992), "Organizational prospects, influence costs, and ownership changes", Journal of Economics and Management Strategy 1:9 35.

Morgan D.P., et al. (2004) "Bank Integration and State Business Cycles" The Quarterly Journal of Economics, November 2004.

Ostry, D, A. Ghosh, K.Habermeier, M. Chamon, M.Qureshi and D. Reinhardt (2010) 'Capital Inflows: the Role of Controls, 'IMF Staff Position Note', SPN/10/04.

Ozbas, O., and Scharfstein D., (2008), "Evidence on the Dark Side of Internal Capital Markets, Review of Financial Studies".

Rajan R.G., et al (2000) "The Cost of Diversity: The Diversification Discount and Inefficient Investment".

Scharfstein, D.S. (1998), "The dark side of internal capital markets II: evidence from diversified conglomerates", NBER Working Paper 6352 (NBER, Cambridge, MA).

Scharfstein, D.S., and Stein J.C., (1990), "Herd behavior and investment", American Economic Review 80:465 479.

Scharfstein, D.S., and Stein J.C., (2000), "The dark side of internal capital markets: divisional rentseeking and inefficient investment", Journal of Finance 55:2537 2564.

Shah, S. \& Thakor, A. V., (1987) "Optimal capital structure and project financing" Journal of Economic Theory, Elsevier, vol. 42(2), pages 209-243, August.

Shin, H., and Stulz R., (1998), “Are internal capital markets efficient?", Quarterly Journal of Economics 113:531 552.

Stein, J.C. (1997), "Internal capital markets and the competition for corporate resources", Journal of Finance 52:111 133.

Stein, J.C. (2002), "Information production and capital allocation: decentralized vs. hierarchical firms", Journal of Finance 57:1891 1921. 
Turner, A. (2009), "Too-big-to-fail" banks and Cross Border Capital Flows, message sent on September 7, 2009 to the FSB Standing Committee on Supervision and Regulatory Cooperation.

Whited, T. (2001), "Is it inefficient investment that causes the diversification discount?", Journal of Finance 56:1667 1691.

Williamson, O.E. (1975), "Markets and Hierarchies: Analysis and Antitrust Implications" (Collier Macmillan Publishers, Inc., NY). 